
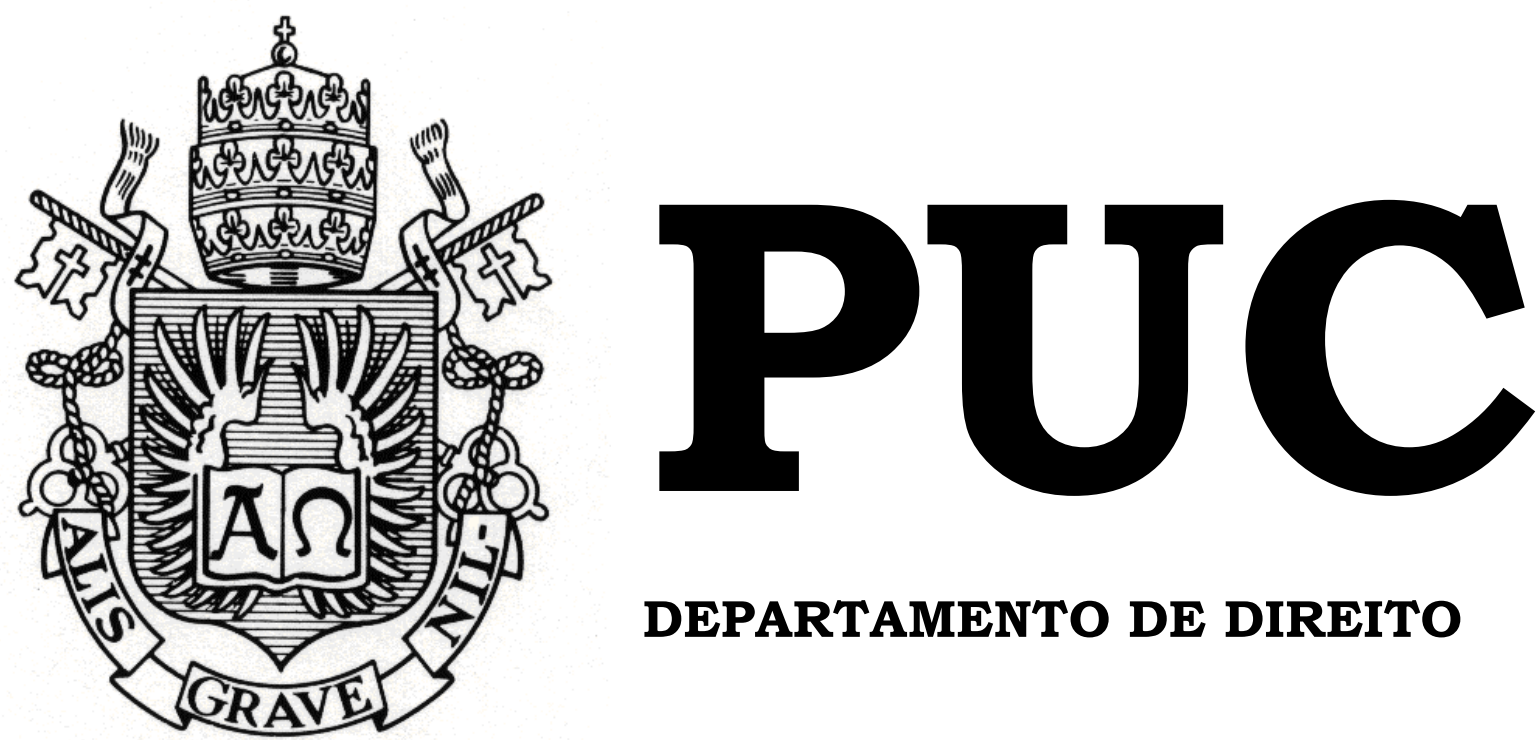

DEPARTAMENTO DE DIREITO

\title{
EIRELI: O NOVO TRATAMENTO JURÍDICO DA UNIPESSOALIDADE NO DIREITO BRASILEIRO
}

por

DIANA CAIADO BALASSIANO

ORIENTADOR: Julian Fonseca Peña Chediak

2012.1

PONTIFÍCIA UNIVERSIDADE CATÓLICA DO RIO DE

JANEIRO

RUA MARQUÊS DE SÃO VICENTE, 225 - CEP 22453-900

RIO DE JANEIRO - BRASIL 


\title{
EIRELI: O NOVO TRATAMENTO JURÍDICO DA UNIPESSOALIDADE NO DIREITO BRASILEIRO
}

\author{
por \\ DIANA CAIADO BALASSIANO
}

Monografia apresentada ao

Departamento de Direito da Pontificia Universidade

Católica do Rio de Janeiro (PUC-Rio) como exigência final para obtenção do Título de Bacharel em Direito.

Orientador: Julian Fonseca Peña Chediak 
A Tetê, Félix, Bruninho, Dé, Evinha, Kênia, Biju, Mané, Areia, Gabi, Polina, Mauri, Thiago, Luma, Féli, Pri, Pedro, Peter, Mari e Rapha, por toda a ajuda, carinho, paciência e alegria, durantes esses longos anos. 


\section{RESUMO}

Há tempos a comunidade jurídica brasileira reclama pela admissão da limitação da responsabilidade patrimonial do empresário individual. Antes da Lei 12.441/2011, o comerciante singular respondia ilimitadamente, isto é, com todo seu patrimônio, tanto pelas suas dívidas comerciais contraídas em razão de seu empreendimento, quanto pelas suas dívidas civis contraídas em sua vida pessoal e familiar. Nas décadas de 80 e 90, diversos países europeus modificaram sua legislação para criar institutos no intuito de admitir essa limitação. Seja através da sociedade unipessoal ou dos modelos de separação patrimonial, a proteção do comerciante singular se tornou objeto de preocupação internacionalmente. O Brasil, no entanto, resistiu a tal inovação. Apesar das diversas manifestações doutrinárias, a unipessoalidade societária só era admitida temporariamente ou para o caso da subsidiária integral. Além dessas hipóteses, não havia nenhum outro instituto que servisse ao propósito de limitar a responsabilidade patrimonial do empresário individual. A Lei 12.441/2011 criou a EIRELI, empresa individual de responsabilidade limitada, cujo propósito é solucionar essa situação e promover maior segurança para aquele que empreende sozinho. A partir de então, os empresários individuais passam a gozar da mesma proteção conferida aos que se associam. No entanto, com poucos meses de vigência, a nova lei já é objeto de diversos questionamentos.

Palavras Chave: EIRELI. Empresa Individual de Responsabilidade Limitada. Lei 12.441/2011. Empresário Individual. Sociedade limitada. Sociedade Unipessoal. Patrimônio de Afetação. Estabelecimento Individual. Personalidade Jurídica. Sociedade fictícia. 


\section{SUMÁRIO}

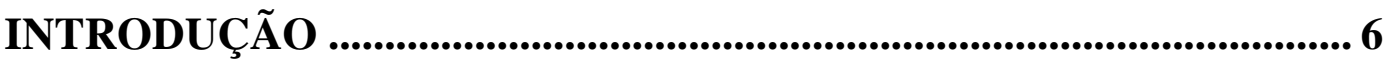

1. A PROTEÇÃO DO EMPRESÁRIO INDIVIDUAL............................. 10

1.1. A sociedade unipessoal ................................................................................. 12

1.2. Separação patrimonial: modelos não societários ................................ 17

2. A UNIPESSOALIDADE NO DIREITO BRASILEIRO ..................... 22

2.1. A subsidiária integral ..................................................................................... 22

2.2. A unipessoalidade temporária.............................................................. 29

2.2.1. Unipessoalidade temporária nas Sociedades Anônimas ........ 30

2.2.2. Unipessoalidade temporária nas Sociedades Limitadas .......... 33

3. A UNIPESSOALIDADE NO DIREITO COMPARADO ................... 35

3.1. Do Direito Português ...................................................................................... 37

3.1.1 Estabelecimento Individual de Responsabilidade Limitada.... 37

3.1.2 A sociedade unipessoal por quotas ............................................. 40

3.2. Do Direito Francês: ................................................................................. 43

3.2.1. Enterprise Unipersonnelle à Responsabilité Limitée .............. 44

3.2.2. Entrepreneur Individuel à Responsabilité Limitée .................... 47

4. EMPRESA INDIVIDUAL DE RESPONSABILIDADE LIMITADA

- EIRELI ............................................................................................................................5 51

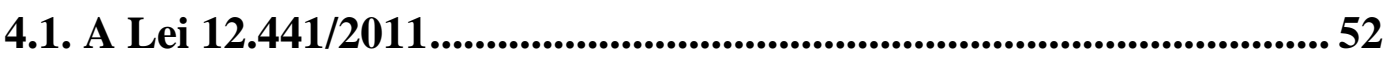

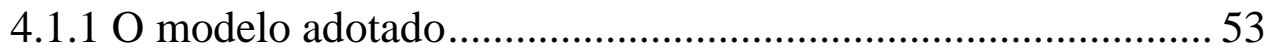

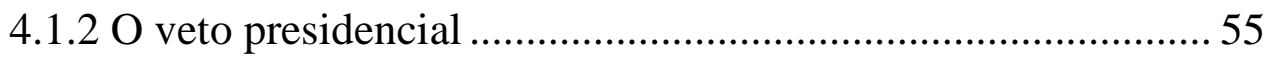

4.2. Críticas à Lei 12.441/2011 ...............................................................56

4.2.1 A natureza jurídica da EIRELI .............................................. 56

4.2.2 Constituição da EIRELI por pessoa jurídica ............................. 59

4.2.3 O capital mínimo e sua vinculação ao salário mínimo.............. 63

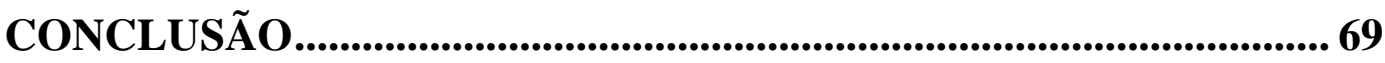

REFERÊNCIAS BIBLIOGRÁFICAS .................................................... 73 


\section{LISTA DE ABREVIATURAS}

12 $2^{\mathrm{a}}$ Diretiva: 12a Diretiva do Conselho Econômico Europeu (89/667/CEE)

CCB: Lei 10.406/2002

CCom: Code de Commerce francês

CRFB: Constituição da República Federativa do Brasil de 1988

CSC: Código das Sociedades Comerciais português de 1986

DNRC: Departamento Nacional de Registro do Comércio

EIRELI: Empresa Individual de Responsabilidade Limitada

EnIRL: Entrepreneur Individuel à Responsabilité Limitée

EsIRL: Estabelecimento Individual de Responsabilidade Limitada

EURL: Enterprise Unipersonnelle à Responsabilité Limitée

JUCERJA: Junta Comercial do Estado do Rio de Janeiro

JUCESP: Junta Comercial do Estado de São Paulo

LSA: Lei 6.404/1976

PPS: Partido Popular Socialista

SARL: Société à Responsabilité Limitée

SQU: Sociedade Unipessoal por Quotas

STF: Supremo Tribunal Federal 


\section{INTRODUÇÃO}

A proteção ao empresário individual é um tema que vem sendo discutido, no Brasil, desde meados do século XX. A CFRB, inclusive, em seu artigo 170, IX, consagrou como princípio geral da atividade econômica brasileira o "tratamento favorecido para as empresas de pequeno porte". Entretanto, até a promulgação da Lei 12.441/2011, o ordenamento jurídico brasileiro não conferia a mesma proteção aos empresários individuais e às sociedades empresárias.

Com efeito, pode-se dizer que, em termos de proteção patrimonial, a legislação brasileira não se mostrava favorável ao empresário individual. Para lançar-se em atividades empresariais, o comerciante singular precisava arriscar a sua fortuna pessoal, assumindo um risco patrimonial maior do que aquele assumido por quem empreendesse com um sócio.

O manto da personalidade jurídica das sociedades protege os seus sócios de cobranças de credores, limitando a sua responsabilidade patrimonial na medida em que é a sociedade que responde pelas dívidas por ela contraídas. Os empresários individuais, inversamente, respondiam com a integralidade do seu patrimônio individual e familiar pelas dívidas contraídas em razão da sua atividade comercial.

Esse regime se mostra especialmente contraditório quando se observa que os empresários individuais constituem uma parcela significativa das iniciativas privadas. Conforme dados obtidos junto ao DNRC $^{1}$, entre os anos de 1985 e 2005, das 8.915.890 (oito milhões, novecentas e quinze mil, oitocentas e noventa) empresas constituídas no Brasil, 4.569.288 (quatro milhões, quinhentas e sessenta e nove mil, duzentas e oitenta e oito) são firmas individuais, o que representa, aproximadamente, $51 \%$ (cinquenta e um por cento) da quantia total. Observa-se, ainda, que dos $49 \%$ (quarenta e nove por cento) restantes as

\footnotetext{
${ }^{1}$ Estatísticas disponíveis no website do DNRC, em http://www.dnrc.gov.br/. Acesso em 25 de abril de 2012
} 
sociedades limitadas representam a grande maioria, correspondendo a 4.300.257 (quatro milhões, trezentas mil, duzentas e cinquenta e sete) sociedades limitadas.

Ainda que não possuam caráter absoluto, pois devem ser interpretados em conjunto com outros fatores, referidos números, certamente, demonstram a representatividade das iniciativas empresariais de menor vulto. Contudo, mesmo diante disso, o legislador brasileiro esperou até 2011 para conferir a merecida proteção patrimonial aos comerciantes individuais.

Defronte a tal realidade, a sociedade fictícia foi a forma eleita, por excelência, pelo comerciante individual para proteger seu patrimônio pessoal. Ao invés de empreender arriscando seu patrimônio familiar, o empresário passou a se utilizar de "testas-de-ferro", "sócios de favor" ou "homens-de-palha" para constituir sociedades de fachada.

São elas sociedades fictícias, em que 01 (um) dos sócios, efetivamente, não participa da sociedade - figuração necessária para que se possa preencher o requisito instituído pelo artigo 981 do CCB, o qual exige o mínimo de 02 (duas) pessoas para a constituição de uma sociedade limitada. Com isso, o verdadeiro empresário pode se beneficiar da proteção conferida pela limitação da sua responsabilidade patrimonial.

A utilização das sociedades fictícias, contudo, implica um grave risco para seus sócios, que consiste na caracterização de simulação. Caso se venha a considerar o ato de constituição da sociedade um ato simulado, isso poderá levar à desconsideração da personalidade jurídica de tal sociedade e à consequente responsabilização pessoal de seus sócios. A jurisprudência, inclusive, mostra-se inclinada a admitir esse entendimento ${ }^{2}$.

Apesar da aparente irregularidade que caracteriza as sociedades fictícias, não há nenhuma restrição legal, no Brasil, para a constituição de sociedade limitada com tamanha disparidade na participação dos sócios no capital social. A difusão das sociedades fictícias demonstra a preferência do

\footnotetext{
${ }^{2}$ FILHO, Calixto Salomão. A sociedade unipessoal. São Paulo: Malheiros, 1995. p. 109.
} 
meio empresarial pelo modelo societário de limitação de responsabilidade, conhecido como unipessoalidade societária ou sociedade unipessoal.

No entanto, não faz tanto tempo assim que a sociedade unipessoal era vista como uma mera curiosidade teórica. O Anstalt, instituído pelo Principado de Liechtenstein, apresentava-se como a única exceção aos demais ordenamentos, que não admitiam essa proteção do comerciante. Todavia, somava-se ao repúdio à sociedade unipessoal que se propagava em parte da doutrina a sensação de fraude decorrente da fama do principado de ser um paraíso fiscal ${ }^{3}$.

Antônio Martins Filho tratou magistralmente sobre a necessidade de atualização das leis para se adequar às transformações sociais. Segundo o autor:

\begin{abstract}
A conveniência de uma revisão periódica dos códigos constitue (sic) matéria que, pela sua própria natureza, não pode comportar contestação. Decorre da circunstância de que as leis, tal qual os indivíduos a que se destinam servir, sofrem também a ação incoercível do tempo. E desde que lhes falta o atributo da imutabilidade, terão necessàriamente (sic) de se ajustar aos novos imperativos sociais, resultantes da lei da evolução. ${ }^{4}$
\end{abstract}

Na tentativa de resolver a situação de vulnerabilidade do empresário individual, a Lei 12.441/2011 criou a figura da empresa individual de responsabilidade limitada, denominada EIRELI. No entanto, o novo instituto já nasceu cercado por dúvidas e incertezas com potencial de impossibilitar a concretização do objetivo do legislador. Os questionamentos a respeito da EIRELI recaem, principalmente, sobre a sua natureza jurídica, a possibilidade de constituição por pessoa jurídica e o capital mínimo exigido para a sua constituição.

O objetivo deste estudo é discutir tais aspectos, no mínimo polêmicos, envolvendo o modelo escolhido pelo legislador brasileiro.

\footnotetext{
${ }^{3}$ FILHO, Calixto Salomão. A sociedade unipessoal. São Paulo: Malheiros, 1995. p. 9.

${ }^{4}$ FILHO, Antônio Martins. Limitação da Responsabilidade do Comerciante Individual. Tese apresentada ao Congresso Jurídico comemorativo do cinquentenário de fundação da Faculdade de Direito da Universidade do Rio Grande do Sul. Publicação da Faculdade de Direito do Ceará, maio de 1950. p. 13.
} 
Pretende-se, em primeiro plano, tentar entender como o novo instituto foi recebido pela comunidade jurídica brasileira e qual o tratamento que the está sendo conferido tanto pela doutrina quanto pela jurisprudência nacional. Em segundo plano, almeja-se compreender os modelos já existentes para atingir o objetivo do legislador e desenvolvimento desse tema no Brasil.

Neste sentido, serão tratadas, no Capítulo 1 , as questões gerais envolvendo a problemática da proteção do empresário individual. Será discutida, brevemente, a evolução teórica do tema e os 03 (três) modelos de que se tem notícia, usados para limitar a responsabilidade ou separar o patrimônio empresarial do comerciante singular. Esse capítulo inicial pretende, portanto, fornecer as noções preliminares para a discussão mais aprofundada da proteção do empresário no Brasil e em outros países.

Em seguida, será discutida a evolução, na legislação brasileira, das opções societárias para o exercício da atividade empresarial individualmente. Será abordado o instituto da subsidiária integral e a unipessoalidade superveniente, de forma a demonstrar que o direito brasileiro possuía uma barreira histórica à aceitação da unipessoalidade originária.

No Capítulo 3, passar-se-á à análise dos modelos adotados em Portugal e na França. A escolha de tais países se justifica pelo fato de ambos terem adotado, em diferentes épocas, 02 (dois) modelos diferentes de proteção do empresário: o societário e o patrimônio de afetação. Curiosamente, ambos os países tiveram experiências opostas com as suas opções.

Por fim, no Capítulo 4 serão tratadas as complexidades que a EIRELI oferece. Serão abordados o intuito do legislador e o modelo escolhido, bem como o veto presidencial à Lei 12.441/2011. Será objeto de estudo a sua natureza jurídica, a limitação para constituição por pessoas jurídicas e a constitucionalidade da previsão de capital mínimo. 


\section{A PROTEÇÃO DO EMPRESÁRIO INDIVIDUAL}

O primeiro estudo de que se tem notícia, no Brasil, sobre a importância de se conferir maior proteção ao empreendedor que exerce suas atividades individualmente é de autoria de Trajano de Miranda Valverde. Em 1943, ele foi autor de um artigo publicado na Revista Forense onde defendia a conveniência de se permitir a criação de estabelecimentos autônomos às pessoas físicas e jurídicas. Dessa forma, conferir-lhes-ia a separação patrimonial necessária para limitar a responsabilidade do instituidor até certa soma 5 .

O artigo ensejou a apresentação, em 1947, do Projeto de Lei 201, de autoria do Deputado Fausto de Freitas e Castro, no qual se pretendia autorizar a constituição de empresas individuais de responsabilidade limitada ${ }^{6}$. Entretanto, em razão de pareceres negativos que o projeto recebeu por parte das comissões pelas quais tramitou, o deputado retirou-o antes que fosse votado ${ }^{7}$.

Outro momento importante para o desenvolvimento do tema no Brasil foi o Congresso Jurídico Nacional Comemorativo do Cinquentenário da Faculdade de Direito de Porto Alegre, realizado em 1950, onde se destacaram as proposições de Antônio Martins Filho e de Salvador Perrota. Suas proposições sobre a limitação da responsabilidade do empresário individual chegaram a ser aceitas com reservas e recomendações de maior estudo do assunto e das garantias dos credores ${ }^{8}$.

Em 1956, Sylvio Marcondes Machado publicou um livro onde defendia a proteção do empresário individual por meio da criação de um patrimônio separado, que reuniria os bens aos quais ficaria limitada a

\footnotetext{
${ }^{5}$ VALVERDE, Trajano de Miranda. Estabelecimento Autônomo. Revista Forense. Rio de Janeiro: Forense, v. 96, ano XL, n. 486, p. 571-585, dezembro de 1943, apud BRUSCATO, Wilges Ariana. Empresário Individual de Responsabilidade Limitada. São Paulo: Quartier Latin, 2005. p. 63.

${ }^{6}$ Projeto de Lei 201 de 1947. Disponível em http://www.camara.gov.br/proposicoesWeb/ficha detramitacao?idProposicao=173047. Acesso em 25 de abril de 2012.

${ }^{7}$ BRUSCATO, Wilges Ariana. Era uma vez a empresa individual de responsabilidade limitada. Disponível em http://www.wilges.com.br/eraumavez.pdf. Acesso em 08 de abril de 2012.

${ }^{8}$ BRUSCATO, Wilges Ariana. Empresário Individual de Responsabilidade Limitada. São Paulo: Quartier Latin, 2005. p. $65-66$.
} 
responsabilidade pelas dívidas oriundas das suas atividades empresariais.

Em 1999, a Portaria 145 do Ministério da Justiça nomeou uma comissão para a elaboração de um anteprojeto de lei que regulasse as sociedades de responsabilidade limitada. A Comissão era integrada pelos ilustres: Arnoldo Wald, como presidente, e Jorge Lobo, como relator, e seus membros eram César Asfor Rocha, Alfredo Lamy Filho, Egberto Lacerda Teixeira e Waldírio Bugarelli. O anteprojeto destinou um capítulo inteiro à regulamentação das empresas individuais de responsabilidade limitada ${ }^{9}$.

No direito comparado, a temática da limitação da responsabilidade do empresário individual e do problema das sociedades fictícias remonta a 1910, quando o jurista austríaco Oskar Pisko apresentou um projeto de lei tratando desse assunto. A tese defendida por Pisko visava a possibilitar a instituição de um patrimônio destinado, exclusivamente, à empresa, por meio da técnica da afetação patrimonial. Deve-se ao projeto legislativo de Oscar Pisko o mérito de ter captado a atenção dos juristas para a importância de se limitar a responsabilidade do empresário individual ${ }^{10}$.

Em 1948, o assunto foi minuciosamente analisado por António de Arruda Ferrer Correia em seu livro sobre as sociedades fictícias e unipessoais. Ainda que sustentasse que a sociedade originariamente unipessoal fosse inconcebível, o autor reconhece que, na realidade, tais sociedades já existiam. Eram elas as sociedades fictícias, que desde a origem pertenciam a um único sócio e já integravam o dia a dia dos operadores do direito. Conforme relata o autor:

\begin{abstract}
Mas o que já pertence ao domínio do possível é que dos fundadores da sociedade todos à excepção (sic) de um, por acordo das partes, devam assumir a posição de meros sócios fictícios: não lhes será exigido que concorram para a formação ou integração do capital social, nem que realizem na empresa qualquer actividade (sic) própria de sócios (salvo a que for estritamente necessária à manutenção da aparência) - e em contrapartida não lhes pertencerá qualquer direito à percepção de dividendos, nem às chamadas quotas de liquidação, nem a qualquer forma de
\end{abstract}

\footnotetext{
${ }^{9}$ BRUSCATO, Wilges Ariana. Empresário Individual de Responsabilidade Limitada. São Paulo: Quartier Latin, 2005. p. 246 - 247.

${ }^{10}$ COSTA, Ricardo Alberto Santos. A sociedade por quotas unipessoal no direito português. Coimbra: Almedina, 2002. p. 173 - 174. Nota de rodapé $n^{\circ} 142$.
} 
ingerência na administração da sociedade. Há uma só pessoa interessada na empresa - e, seja o que for que venha a dizer-nos o Direito acerca disso, a verdade é que de facto (sic), econòmicamente (sic), a empresa pertence a essa pessoa. Estamos, pois, em presença de uma sociedade de facto (sic) e desde as origens nas mãos de um só. ${ }^{11}$ (grifado no original)

No entanto, não é essa a única maneira de se proteger patrimonialmente o comerciante individual. Há diferentes modelos difundidos no direito comparado que podem servir a tal propósito. Por vezes, eles envolvem a modalidade societária, como é o caso da sociedade unipessoal, e, por vezes, apenas se utilizam da técnica da separação patrimonial, seja por meio da afetação de parte do patrimônio do comerciante, seja pela personalização de uma parcela do seu patrimônio. Passamos a analisar, brevemente, tais hipóteses.

\subsection{A sociedade unipessoal}

A sociedade unipessoal, quando constituída por uma pessoa natural, representa a forma societária de limitação da responsabilidade do comerciante. Quando constituída por pessoa jurídica, ela representa uma forma de organização administrativa de grupos econômicos ${ }^{12}$. A sociedade unipessoal consiste na previsão legal de que apenas 01 (uma) pessoa pode, regularmente, constituir uma sociedade.

Essa modalidade, todavia, apresenta resistência histórica por parte de alguns doutrinadores porque o nascimento das sociedades esteve muito vinculado à concepção contratualista de sociedade. De acordo com a teoria contratualista clássica, a sociedade decorre do acordo de vontades das partes que a constituem, acordo este cuja natureza é de contrato bilateral. Assim, ao constituir uma sociedade os sócios estariam celebrando um contrato entre si, caracterizando 02 (dois) polos de interesses antagônicos.

No entanto, a teoria contratualista clássica sofreu um abalo quando

\footnotetext{
${ }^{11}$ CORREIA, António de Arruda Ferrer. Sociedades Fictícias e Unipessoais. Coimbra: Atlântida, 1948. p. 3.

${ }^{12}$ FILHO, Calixto Salomão. A sociedade unipessoal. São Paulo: Malheiros, 1995. p. 13-14.
} 
da publicação da obra de Tullio Ascarelli, na qual ele defendia que os contratos bilaterais não contemplavam perfeitamente todas as relações existentes no quadro societário de uma sociedade ${ }^{13}$. Para Ascarelli, o acordo de vontades entre os sócios melhor se define como um contrato plurilateral, no qual as partes possuem direitos e obrigações entre si e conjugam seus esforços para um fim comum. Dessa forma, não haveria, necessariamente, uma contraposição de interesses entre 02 (dois) polos distintos.

Observe-se que a teoria contratualista foi fortemente absorvida pelo CCB, o qual prevê, em seu artigo 981, que "Celebram contrato de sociedade as pessoas que reciprocamente se obrigam a contribuir (...)". Dessa forma, como não parece razoável nem lógica a ideia de alguém contratar consigo mesmo, os ordenamentos nos quais a sociedade é concebida como um contrato têm dificuldade em aceitar a ideia da sociedade unipessoal.

No entanto, aos poucos as teorias contratualistas perderam espaço para teorias alternativas. Nesse conjunto, destacam-se as teorias institucionalistas e as que veem as sociedades como um contratoorganização.

Segundo a teoria institucionalista, cujo maior percursor foi o alemão Walter Rathenau, a empresa seria um "instrumento a serviço do interesse coletivo (em oposição ao interesse meramente privado dos sócios) e teria por função (...) contribuir de forma relevante para o desenvolvimento do país (...)"14. O institucionalismo, no fundo, veio realçar a importância do princípio da preservação da empresa e da existência de um interesse por trás da sociedade, que extrapola os interesses particulares dos sócios.

Ao tratar do institucionalismo alemão, berço dessa forma de concepção da sociedade, Calixto Salomão Filho ${ }^{15}$ destaca que

\footnotetext{
${ }^{13}$ BORBA, José Edwaldo Tavares. Direito Societário. $11^{\mathrm{a}}$ ed. Rio de Janeiro: Renovar, 2008. p. 29-30.

${ }^{14}$ FACCHIM, Tatiana. A sociedade unipessoal como forma organizativa da micro e pequena empresa. São Paulo, 2010. p. 62. Dissertação (Mestrado em Direito Comercial) - Faculdade de Direito da Universidade de São Paulo.

${ }^{15}$ FILHO, Calixto Salomão. A sociedade unipessoal. São Paulo: Malheiros, 1995. p. 49.
} 
(...) a definição de interesse social como algo diverso dos interesses contrapostos dos sócios e a pressuposição de sua persecução pelos órgãos sociais não eliminam o conflito de interesses da dialética societária. Ao contrário, reforçam, porque introduz no interior dos órgãos societários representações de interesses efetivamente contrapostos.

Por atentar para a existência de outros interesses além daqueles dos sócios, à teoria institucionalista não importaria a quantidade de sócios compondo a sociedade. A ausência de pluralidade não implicaria a confusão de interesses entre sócio e sociedade. Admite-se, portanto, a existência de sociedades unipessoais, pois a pluralidade social não é um elemento fundamental para se atingir tais interesses ${ }^{16}$.

A teoria do contrato-organização, por sua vez, dá prevalência à noção de atividade, de atos coordenados dentro de uma estrutura corporativa, e não aos participantes. O cerne da teoria do contratoorganização está na diferenciação entre contrato de permuta e contrato de associação. Neste, a função primordial é a criação de uma organização, em contraposição à criação de direitos subjetivos que prevalece naquele.

Ao entender a relação entre os sócios como um contrato associativo, a organização se torna o valor nuclear da sociedade. Com isso, afasta-se a sociedade do propósito de criação de direitos subjetivos e a pluralidade de sócios perde importância. A constituição da sociedade se concentra, pois, na sua formação e estruturação. Da mesma forma, o interesse social deixa de estar vinculado à conjugação de interesses dos sócios ${ }^{17}$.

Quando visualizada como meio organizativo da atividade empresarial, isto é, como um conjunto de regras sobre administração e estrutura da atividade, a ideia de sociedade é desvinculada do requisito da pluralidade de pessoas. O agrupamento de pessoas deixa de ser um fator relevante para a sociedade e a unipessoalidade deixa de ser um impedimento para a sua constituição. Os princípios da individualidade e da perpetuidade do patrimônio social ganham relevância, dispensando o requisito da pluralidade.

\footnotetext{
${ }^{16}$ FILHO, Calixto Salomão. A sociedade unipessoal. São Paulo: Malheiros, 1995. p. 50.

${ }^{17}$ FILHO, Calixto Salomão. A sociedade unipessoal. São Paulo: Malheiros, 1995. p. 58-59.
} 
"As sociedades corresponderiam, desse modo, a estruturas organizativas que servem de instrumento para obtenção de determinado fim."18 Assim, seria possível conceber uma sociedade unipessoal sem maiores esforços, pois 01 (uma) pessoa poderia criar uma empresa, individualmente, por meio da organização que o direito societário oferece.

Vale observar que o conceito de sociedade, como tradicionalmente entendido, foi construído a partir de uma realidade social, da necessidade, observada ao longo dos anos, de se proteger o patrimônio pessoal daqueles que se arriscam em empreendimentos econômicos. Trata-se, portanto, de uma construção jurídica que pode ser transposta pela aceitação de uma nova construção jurídica: um novo conceito de sociedade formada por 01 (um) só sócio. É importante ressaltar que a unipessoalidade já é aceita em diversos casos, inclusive no ordenamento brasileiro, como será analisado abaixo.

Superada a discussão sobre a natureza jurídica das sociedades, a unipessoalidade societária não representaria nenhum maior risco aos credores do que uma sociedade constituída por 02 (dois) sócios ou mais. A manipulação fraudulenta da sociedade pode ocorrer tanto na sociedade pluripessoal quanto na unipessoal. A solução para resolver esses casos se encontra na teoria da desconsideração da personalidade jurídica e na busca da satisfação dos credores no patrimônio pessoal dos sócios ${ }^{19}$.

Ricardo Alberto Santos $\operatorname{Costa}^{20}$ descreve alguns dos principais comportamentos abusivos quando se trata das sociedades unipessoais. São eles a confusão patrimonial entre sócio e sociedade; a subcapitalização da sociedade; a concessão de financiamentos do sócio para a sociedade, quando a remessa poderia ter sido efetuada via aumento de capital; a concessão de empréstimos pela sociedade ao sócio; dentre outros. Percebese que todos os riscos enumerados pelo autor se referem à depauperação do

\footnotetext{
${ }^{18}$ FACCHIM, Tatiana. A sociedade unipessoal como forma organizativa da micro e pequena empresa. São Paulo. 2010. p. 67. Dissertação (Mestrado em Direito Comercial) - Faculdade de Direito da Universidade de São Paulo.

${ }^{19}$ FILHO, Calixto Salomão. A sociedade unipessoal. São Paulo: Malheiros, 1995. p. 87.

${ }^{20}$ COSTA, Ricardo Alberto Santos. A sociedade por quotas unipessoal no direito português. Coimbra: Almedina, 2002. p. 49-50.
} 
patrimônio da sociedade e, consequentemente, à quebra das garantias dos credores.

Segundo o autor, tais situações abusivas deveriam ser objeto de um sistema de controle e fiscalização efetivos que as impedisse de acontecer. Dentre esses mecanismos, a publicidade dos atos da sociedade unipessoal possibilitaria aos próprios credores realizar tal fiscalização. A publicidade pode se dar tanto com a obrigação de registro imediato da sociedade tornada unipessoal quanto com a obrigatoriedade da inserção da expressão "unipessoal" em seu nome empresarial.

Vale observar que a $12^{\mathrm{a}}$ Diretiva, que será analisada mais adiante, tratou especificamente das regras sobre publicidade do caráter unipessoal da sociedade e da identidade do sócio remanescente.

A modalidade societária oferece, ainda, a possibilidade de se utilizar um formato que já é usual nos meios empresariais - as sociedades. Não haveria necessidade de que o meio empresarial se familiarizasse com uma nova fórmula, tal como ocorre com a personalização de um novo ente. Além disso, a sistemática da disregard doctrine em casos de fraude e abuso da personalidade jurídica lograria proteger os credores da sociedade unipessoal, permitindo que eles satisfizessem seus créditos com o patrimônio pessoal do sócio.

Isto posto, percebe-se que a sociedade unipessoal se apresenta como uma opção prática, simples e viável para a proteção e o desenvolvimento do empresário individual. Contanto que as regras para formação do patrimônio social e para administração da sociedade estejam bem delimitadas e que a desconsideração da personalidade jurídica da sociedade seja aplicada pelos tribunais com firmeza e dentro dos limites legais, ela não representa nenhum risco maior do que aquelas das sociedades pluripessoais.

Prática, porque sua inclusão toma por base toda a estrutura legal já criada para as sociedades limitadas. Simples, porque ela exigiria apenas algumas poucas adaptações para regular a ausência de pluralidade social, tais como deliberações sociais e publicidade de atos. E, por fim, viável 
porque o único impedimento real que se identifica para sua aceitação é uma barreira teórica e doutrinária que se funda no conservadorismo de uma concepção jurídica criada a partir de uma realidade social já ultrapassada.

\subsection{Separação patrimonial: modelos não societários}

As modalidades de separação patrimonial, que não fazem uso da forma societária, dividem-se, basicamente, na afetação patrimonial e na personalização de um novo ente.

A técnica da afetação patrimonial consiste em destacar uma parcela do acervo de bens do empresário e afetá-la a um propósito específico - suas atividades empresariais. Em decorrência disso, o empresário passa a ser titular de 02 (dois) núcleos patrimoniais distintos, sendo 01 (um) destinado às suas atividades civis e o outro, às suas atividades comerciais. Dessa forma, resta assegurada a autonomia dos grupamentos de bens e a garantia dos direitos de terceiros ${ }^{21}$.

O patrimônio de afetação, nesse sentido, possibilita que o empresário individual limite seu risco, pois seu patrimônio pessoal não se sujeita às suas dívidas comerciais. Ao mesmo tempo, ele representa uma garantia aos seus credores comerciais porque eles deixam de ter como concorrentes os credores pessoais do empresário individual ${ }^{22}$.

A característica dessa técnica que a diferencia da técnica da personalização de um novo ente é que, apesar de se criar um novo núcleo patrimonial, o patrimônio de afetação é desprovido de personalidade. Ele possui autonomia com relação ao patrimônio civil do seu instituidor, mas ainda se trata de uma massa de bens, sem personalidade jurídica autônoma. Ele é objeto de direito enquanto o empresário é sujeito de direito.

Caio Mário da Silva Pereira ${ }^{23}$ ilustra que "A doutrina tradicional

\footnotetext{
${ }^{21}$ COSTA, Ricardo Alberto Santos. A sociedade por quotas unipessoal no direito português. Coimbra: Almedina, 2002. p. 169.

${ }^{22}$ FILHO, Calixto Salomão. A sociedade unipessoal. São Paulo: Malheiros, 1995. p. 27-28.

${ }^{23}$ PEREIRA, Caio Mário da Silva. Instituições de Direito Civil. vol. I. $22^{\mathrm{a}}$ ed. Rio de Janeiro: Forense, 2008. p. 394-395.
} 
sustenta que o patrimônio é uno e indivisivel no sentido de que não é possível conceber a sua pluralidade na mesma pessoa." (grifado no original). Parte-se da premissa de que o patrimônio é uma expressão da personalidade. Dessa forma, todo indivíduo tem 01 (um) e apenas 01 (um) único patrimônio, pois não é possível conceber uma pessoa com uma pluralidade de personalidades.

Para os unitaristas, o patrimônio só poderia ser detido por pessoas, sejam elas jurídicas ou naturais, e cada pessoa teria, necessariamente, 01 (um) patrimônio, o qual seria inseparável dela ${ }^{24}$. Não se permite, portanto, a criação de patrimônios especiais não personalizados.

Entretanto, o "princípio da unidade do patrimônio implica confundir as noções de patrimônio e a de personalidade" ${ }^{25}$. Nesse sentido, a doutrina mais moderna entende como sendo objetivo, e não subjetivo, o vínculo do patrimônio, o que viabiliza a existência de mais de 01 (um) patrimônio para uma pessoa. A teoria da afetação patrimonial foi incorporada por nosso ordenamento jurídico, por exemplo, para os casos de incorporação imobiliária previstos na Lei 4.591/1964, conforme modificada pela Lei $10.931 / 2004$.

Em tais situações, admite-se a separação de parte do patrimônio de um sujeito para determinado fim. Trata-se da reunião de bens que compunham, originalmente, o patrimônio pessoal do instituidor e que passam a ser destinados a uma finalidade específica. Sobre essa massa de bens recai uma restrição em benefício de tal finalidade.

Para Caio Mário da Silva Pereira ${ }^{26}$, o patrimônio de afetação se caracteriza como um patrimônio especial, dentro do patrimônio geral do instituidor. Seu objetivo final seria o de garantir os direitos dos credores cujos créditos se refiram àquela atividade específica para a qual foi destinado o patrimônio afetado.

\footnotetext{
${ }^{24}$ FILHO, Calixto Salomão. A sociedade unipessoal. São Paulo: Malheiros, 1995. p. 28. Nota de rodapé $\mathrm{n}^{\circ} 74$.

${ }^{25}$ FILHO, Calixto Salomão. A sociedade unipessoal. São Paulo: Malheiros, 1995. p. 36.

${ }^{26}$ PEREIRA, Caio Mário da Silva. Instituições de Direito Civil. vol. I. $22^{\mathrm{a}}$ ed. Rio de Janeiro: Forense, 2008. p. 399.
} 
Por um lado, protege-se o instituidor porque tais credores não poderiam recorrer ao patrimônio pessoal do devedor para ver satisfeitas suas dívidas e, por outro, protegem-se os credores porque o instituidor do patrimônio de afetação não poderia utilizar tais bens para finalidade diversa. Percebe-se, pois, a dupla finalidade do patrimônio de afetação.

Outra modalidade de proteção patrimonial do empresário individual é a personalização de um novo ente. Esse modelo se assemelha à modalidade da afetação patrimonial por separar uma parte do patrimônio civil do comerciante e destiná-la às atividades empresariais. No entanto, o patrimônio afetado seria dotado de personalidade jurídica própria, distinta daquela de seu titular.

Trata-se, portanto, de uma nova pessoa jurídica, comumente referida como empresa individual de responsabilidade limitada. Referido patrimônio, transformado em pessoa jurídica autônoma, seria titularizado pelo empresário e centralizaria as relações jurídicas originadas das suas atividades comerciais. Ressalte-se que essa foi, inclusive, a opção adotada pelo legislador brasileiro.

$\mathrm{Na}$ doutrina estrangeira, foi Roger Ischer, em oposição a Oscar Pisko, quem originalmente defendeu a técnica da personalização do patrimônio. Segundo o autor, o próprio conceito de limitação da responsabilidade do empresário estaria tradicionalmente vinculado ao instituto da personalidade jurídica ${ }^{27}$. Vale observar que a opção pela personalização da empresa traria todos os efeitos da criação de uma nova pessoa jurídica, dentre eles capacidade processual e negocial próprias e autonomia patrimonial com relação ao seu instituidor.

No Brasil, Antônio Martins Filho foi um dos defensores dessa opção. Em sua tese, defende que a empresa individual dotada de personalidade jurídica é uma forma direta de limitação da responsabilidade do comerciante individual. A sociedade unipessoal seria um meio indireto e

\footnotetext{
${ }^{27}$ COSTA, Ricardo Alberto Santos. A sociedade por quotas unipessoal no direito português. Coimbra: Almedina, 2002. p. 177.
} 
anormal de se atingir tal objetivo. No entanto, o próprio autor admite que "não existem razões jurídicas decisivas contra o reconhecimento da chamada sociedade unipessoal" 28 .

Ricardo Alberto Santos Costa $^{29}$ informa, ainda, sobre uma derivação da teoria da personalização, que consiste em aproveitar o instituto das fundações para evitar a criação de uma figura anômala. Conforme explica o autor, essa teoria não veria obstáculos racionais para que a fundação ganhasse uma função alternativa e desprovida do altruísmo. O mesmo raciocínio já teria sido aplicado, por exemplo, para as sociedades civis, que não têm destinação comercial nem visam à obtenção do lucro como as sociedades empresárias.

Esse modelo será analisado com detalhes no Capítulo 4, quando se abordar especificamente a Lei 12.441/2011.

Apesar de terem traços característicos próprios, as 02 (duas) modalidades de proteção do empresário individual por meio da separação patrimonial apresentam dificuldades em comum: a possibilidade de entrada de novos sócios no empreendimento e de circulação do empreendimento.

A transferência do patrimônio de afetação implica a necessidade de transferência de todos os ativos que constituem o patrimônio afetado. Já a transferência causa mortis da empresa individual para os herdeiros, por exemplo, implica a necessidade de uma operação de reestruturação do negócio e de constituição de uma sociedade. Da mesma forma, para a admissão de novos parceiros no negócio seria imprescindível a criação de um novo ente, uma sociedade, o que levaria, consequentemente, às mesmas dificuldades da transferência do empreendimento ${ }^{30}$.

Em caso de falecimento do empresário, se não for feita a

\footnotetext{
${ }^{28}$ FILHO, Antônio Martins. Limitação da Responsabilidade do Comerciante Individual. Tese apresentada ao Congresso Jurídico comemorativo do cinquentenário de fundação da Faculdade de Direito da Universidade do Rio Grande do Sul. Publicação da Faculdade de Direito do Ceará, maio de 1950. p. 61

${ }^{29}$ COSTA, Ricardo Alberto Santos. A sociedade por quotas unipessoal no direito português. Coimbra: Almedina, 2002. p. 179.

${ }^{30}$ COSTA, Ricardo Alberto Santos. A sociedade por quotas unipessoal no direito português. Coimbra: Almedina, 2002. p. 209-213.
} 
reestruturação da empresa individual, as formas não societárias implicam a necessidade de liquidação da empresa ou patrimônio, impossibilitando a sua continuidade ${ }^{31}$.

Tais fatores prejudicam a versatilidade desses modelos, porque representam barreiras para a expansão do negócio. Diminuem a sua possibilidade de crescimento e de circulação ao limitar as formas de capitalização da atividade empresária.

Além do suposto impedimento teórico para a unipessoalidade societária, os modelos de separação patrimonial não apresentam vantagens nem resultados que não possam ser alcançados pela sociedade unipessoal ${ }^{32}$. Consequentemente, também não serviriam para acabar com as sociedades fictícias existentes, pois por sua própria natureza não são substitutos para o modelo societário ${ }^{33}$.

A unipessoalidade societária, quando comparada às técnicas de separação patrimonial, mostra-se vantajosa por simplificar as operações acima. A sua transferência pode ser feita tal como a transferência da sociedade limitada e para a admissão de novos sócios basta uma alteração do instrumento constitutivo da sociedade. O raciocínio se aplica igualmente para as operações reversas, de transformação da sociedade pluripessoal em unipessoal.

Em razão de tais aspectos e daqueles apresentados no subcapítulo anterior, a modalidade societária é a melhor opção para regular a limitação da responsabilidade do empresário individual. Nas palavras do professor Jean-Jacques Daigre" ${ }^{34}$ "son choix se recommande par des intérêts théoriques et pratiques indubitables, même s'il peut présenter quelque danger".

\footnotetext{
${ }_{31}^{31}$ FILHO, Calixto Salomão. A sociedade unipessoal. São Paulo: Malheiros, 1995. p. 38-39.

${ }^{32}$ ISFER, Edson. Sociedades unipessoais e empresas individuais - responsabilidade limitada. Curitiba: Juruá, 1996. p. 137.

${ }^{33}$ ISFER, Edson. Sociedades unipessoais e empresas individuais - responsabilidade limitada. Curitiba: Juruá, 1996. p. 142.

${ }^{34}$ DAIGRE, Jean-Jacques. La société unipersonnelle. Revue internationale de droit comparé. Paris, Société de Législation Comparée, v. 42, n. 2, 1990.
} 


\section{A UNIPESSOALIDADE NO DIREITO BRASILEIRO}

Antes da Lei 12.441/2011, o ordenamento jurídico nacional permitia a unipessoalidade apenas em alguns casos específicos e nenhum deles no intuito de proteger o empresário individual. São hipóteses de unipessoalidade aceitas no direito brasileiro (i) a subsidiária integral e (ii) a unipessoalidade temporária, tanto para sociedades anônimas quanto para sociedades limitadas. Essas hipóteses permanecem existindo depois da Lei 12.441/2011, com pouquíssimas alterações.

Nos subcapítulos a seguir, serão abordados os principais aspectos concernentes à constituição da subsidiária integral e as restrições para tal, bem como as implicações relacionadas à unipessoalidade superveniente.

\subsection{A subsidiária integral}

O diploma legal de 1940 exigia o número mínimo de 07 (sete) acionistas para a constituição de uma sociedade anônima ${ }^{35}$. De acordo com o artigo 137, d do Decreto-Lei 2.627/1940, a redução da quantidade de acionistas, não regularizada no prazo legal, acarretava a liquidação da companhia. Paulo Roberto Costa Figueiredo ${ }^{36}$ critica referida determinação, pois não haveria qualquer sentido no número mínimo escolhido, parecendolhe que referida previsão fora uma importação do direito estrangeiro mantida por força da tradição.

O artigo 80, I da LSA diminui para 02 (dois) o número mínimo de acionistas exigido para a constituição de uma sociedade anônima. A LSA trouxe ainda mais uma inovação: a subsidiária integral ${ }^{37}$.

A subsidiária integral foi inspirada na wholly owned subsidiary

\footnotetext{
${ }^{35}$ Artigo 38, $1^{\circ}$ do Decreto-Lei 2.627/1940: “Art. 38. Nenhuma sociedade anônima poderá constituir-se sem que se verifiquem, preliminarmente, os seguintes requisitos: $1^{\circ}$, a subscrição, pelo menos por sete pessoas, de todo o capital social (...)".

${ }^{36}$ FIGUEIREDO, Paulo Roberto Costa. Subsidiaria integral: a sociedade unipessoal no direito brasileiro. São Paulo: Saraiva, 1984. p. 8.

${ }^{37} \mathrm{O}$ funcionamento e a administração da subsidiária integral não serão analisados por não se tratarem do objeto do presente estudo.
} 
norte-americana ${ }^{38}$. Sua criação teve como objetivo superar o uso de sociedades fictícias e dos homens de palha para atingir o número mínimo de acionistas, como descrito na Exposição de Motivos 196/1976, posteriormente convertida na $\mathrm{LSA}^{39}$.

Em 1962, a Seção 47 do Model Act da American Bar Association passou a autorizar a constituição de uma corporation, que seria o modelo societário norte-americano correspondente à sociedade anônima, por 01 (uma) única pessoa, natural ou jurídica. O Model Act foi usado como base para a legislação de diversos estados norte-americanos na época e era aceito como referência para a constituição de corporations ${ }^{40}$.

Sobre a natureza da subsidiária integral, Nelson Eirizik ${ }^{41}$ assevera que se percebe, claramente, "a prevalência do caráter institucional sobre a feição contratualista da companhia". Modesto Carvalhosa ${ }^{42}$ se posiciona no mesmo sentido. Entretanto, Alfredo Lamy Filho e José Luiz Bulhões Pedreira ${ }^{43}$ se atêm à teoria contratualista e explicam que "No momento em que a subsidiária integral admite outro acionista, ou acionistas, forma-se, por adesão, o contrato de sociedade, com a mesma organização social criada pelo ato unilateral."

A subsidiária integral somente pode assumir o tipo de sociedade anônima, pois o artigo 251 da LSA menciona, expressamente, os termos "companhia" e "único acionista". Adicionalmente, o artigo 251 prevê que apenas poderá ser acionista de uma subsidiária integral uma sociedade brasileira, do que se conclui que uma pessoa natural não poderá constituir subsidiárias integrais.

\footnotetext{
${ }^{38}$ CARVAlHOSA, Modesto. Comentários à Lei de Sociedades Anônimas. $4^{\circ}$ vol. tomo II. $3^{\mathrm{a}}$ ed. São Paulo: Saraiva, 2009. p. 128.

${ }^{39}$ Exposição de Motivos 196/1976. Disponível em http://imagem.camara.gov.br/dc 20.asp?selCod ColecaoCsv=D\&Datain=07/08/1976\&txpagina $=0 \&$ txsuplemento $=1 \&$ altura $=650 \&$ largura $=800$. Acesso em 17 de abril de 2012.

${ }^{40}$ PERA, Sergio de. Cuestiones de derecho comercial moderno. Buenos Aires: Astrea, 1974. p. 110-116, apud FIGUEIREDO, Paulo Roberto Costa. Subsidiaria integral: a sociedade unipessoal no direito brasileiro. São Paulo: Saraiva, 1984. p. 39.

${ }^{41}$ EIZIRIK, Nelson. A Lei das S/A Comentada. vol. III. São Paulo: Quartier Latin, 2011. p. 388.

${ }^{42}$ CARVAlHOSA, Modesto. Comentários à Lei de Sociedades Anônimas. $4^{\circ}$ vol. tomo II. $3^{\mathrm{a}}$ ed. São Paulo: Saraiva, 2009. p. 126.

${ }^{43}$ FILHO, Alfredo Lamy; PEDREIRA, José Luiz Bulhões. Direito das Companhias. vol. II. $1^{\text {a }}$ ed. Rio de Janeiro: Forense, 2009. p. 1990 - 1991.
} 
A respeito do tipo societário assumido pelo acionista único, o artigo 251, ao estabelecer que a companhia poderá ser constituída por sociedade brasileira na qualidade de acionista único, não especificou de que tipo de sociedade se trata. Dessa forma, não há qualquer restrição para que outros tipos societários constituam subsidiárias integrais, contanto que a sociedade seja brasileira.

A Exposição de Motivos 196/1976 justificou a exigência da nacionalidade brasileira para o acionista da subsidiária integral sustentando que o dispositivo legal objetivava vedar a submissão do interesse nacional ao interesse estrangeiro. Alfredo Lamy Filho e José Luiz Bulhões Pedreira ${ }^{44}$ explicam que o maior risco da subsidiária integral consiste na possível confusão entre o patrimônio do acionista e o da companhia. Em vista disso, a justiça brasileira teria mais dificuldade em verificar eventual confusão patrimonial se o acionista da subsidiária fosse sociedade estrangeira, cuja sede se localizasse fora do território nacional e que não fosse organizada sob as leis brasileiras.

Há diferentes formas de constituição da subsidiária integral, sendo elas (i) originária; (ii) derivada, por meio da aquisição da totalidade das ações de emissão de uma companhia; e (iii) derivada, pela incorporação de ações prevista no artigo 252 da LSA.

Quanto à primeira modalidade, o artigo 251 da LSA estabelece que a subsidiária integral será constituída por escritura pública. No entanto, Modesto Carvalhosa ${ }^{45}$ e Paulo Roberto Costa Figueiredo ${ }^{46}$ criticam essa disposição, tendo em vista a faculdade que se concede às sociedades anônimas pluripessoais de poderem ser constituídas mediante assembleia geral. Não haveria motivo para a obrigatoriedade de constituição por escritura pública.

\footnotetext{
${ }^{44}$ FILHO, Alfredo Lamy; PEDREIRA, José Luiz Bulhões. Direito das Companhias. vol. II. $1^{\mathrm{a}}$ ed. Rio de Janeiro: Forense, 2009. p. 1989.

${ }^{45}$ CARVALHOSA, Modesto. Comentários à Lei de Sociedades Anônimas. $4^{\circ}$ vol. tomo II. $3^{\mathrm{a}}$ ed. São Paulo: Saraiva, 2009. p. 129.

${ }^{46}$ FIGUEIREDO, Paulo Roberto Costa. Subsidiaria integral: a sociedade unipessoal no direito brasileiro. São Paulo: Saraiva, 1984. p. 76.
} 
Em sentido oposto, Alfredo Lamy Filho e José Luiz Bulhões Pedreira $^{47}$ defendem que a previsão legal se justifica pelo fato de o ato de constituição da subsidiária integral ter natureza jurídica de declaração unilateral de vontade. Além disso, sustentam os autores que a escritura pública seria uma forma mais simples e imune a fraudes.

A segunda modalidade de constituição é através da aquisição, por sociedade brasileira, da totalidade das ações de uma companhia. A doutrina diverge, nesse aspecto, sobre a natureza da subsidiária integral, se sociedade de fato ou de direito.

Nelson Eizirik $^{48}$ argumenta que, por não existir previsão de um procedimento específico, a aquisição da totalidade das ações de uma companhia a converteria, automaticamente, em uma subsidiária integral. $\mathrm{O}$ artigo 206, I, d da LSA, todavia, é inequívoco ao estabelecer, como causa de dissolução de pleno direito da companhia, a redução de seus acionistas a 01 (um), exceção feita para o artigo 251.

Assim, caso se admitisse a conversão automática da sociedade anônima unipessoal em subsidiária integral, o artigo 206, I, d perderia a sua razão de ser. A interpretação da lei, no entanto, deve ser sistemática e, por essa razão, não se pode admitir a conversão automática preconizada pelo autor.

No mesmo sentido, Alfredo Lamy Filho e José Luiz Bulhões Pedreira $^{49}$ defendem a necessidade de manifestação de vontade expressa pelo acionista único. Similarmente, Modesto Carvalhosa ${ }^{50}$ expõe que a subsidiária integral é uma sociedade de direito e, portanto, não pode prescindir da declaração da intenção do acionista único de converter a companhia em subsidiária integral. Também Paulo Roberto Costa

\footnotetext{
${ }^{47}$ FILHO, Alfredo Lamy; PEDREIRA, José Luiz Bulhões. Direito das Companhias. vol. II. $1^{\text {a }}$ ed. Rio de Janeiro: Forense, 2009. p. 1990.

${ }^{48}$ EIZIRIK, Nelson. A Lei das S/A Comentada. vol. III. São Paulo: Quartier Latin, 2011. p. 390.

${ }^{49}$ FILHO, Alfredo Lamy; PEDREIRA, José Luiz Bulhões. Direito das Companhias. vol. II. $1^{\text {a }}$ ed. Rio de Janeiro: Forense, 2009. p. 1990.

${ }^{50}$ CARVALHOSA, Modesto. Comentários à Lei de Sociedades Anônimas. $4^{\circ}$ vol. tomo II. $3^{\mathrm{a}}$ ed. São Paulo: Saraiva, 2009. p. 130.
} 
Figueiredo ${ }^{51}$ defende que a interpretação sistemática da lei leva à conclusão de que é necessária a manifestação da assembleia geral para aprovação da conversão em subsidiária integral.

A terceira e última forma de criação da subsidiária integral se dá pela incorporação das ações de uma companhia, disciplinada no artigo 252 da LSA. A incorporação de ações ocorre quando uma companhia incorpora, ao seu patrimônio, a totalidade das ações de emissão de outra companhia. Consequentemente, a companhia cujas ações foram incorporadas convertese em subsidiária integral.

Ao contrário do que ocorre na incorporação de sociedades, a incorporação de ações não acarreta a extinção da personalidade jurídica da sociedade incorporada. Isso significa que a companhia incorporada continua a existir, mas como subsidiária integral. Com a incorporação de ações, não ocorre a sucessão universal que ocorreria se se estivesse diante de uma incorporação de sociedades. Isso mitiga os riscos para a incorporadora, no caso de a companhia incorporada ter passivos ocultos de qualquer sorte. Os patrimônios de ambas continuam separados.

Como consequência da incorporação de ações, os antigos acionistas da companhia incorporada passam a ser acionistas da incorporadora. As suas ações de emissão da companhia incorporada são trocadas, substituídas pelas ações emitidas pela incorporadora. Aprova-se, em assembleia geral da incorporadora, um aumento de capital a ser subscrito pela diretoria da companhia incorporada e pago com as ações detidas pelos seus acionistas no capital social da incorporada.

Observe-se que os acionistas minoritários da incorporadora perdem seu direito de preferência na subscrição de tal aumento de capital. De acordo com Nelson Eizirik ${ }^{52}$, "O direito de preferência é absolutamente incompatível com a operação, visto que seu exercício simplesmente impediria que as ações da incorporadora fossem entregues aos acionistas da

\footnotetext{
${ }^{51}$ FIGUEIREDO, Paulo Roberto Costa. Subsidiaria integral: a sociedade unipessoal no direito brasileiro. São Paulo: Saraiva, 1984. p. 88.

${ }^{52}$ EIZIRIK, Nelson. A Lei das S/A Comentada. vol. III. São Paulo: Quartier Latin, 2011. p. 399.
} 
sociedade cujas ações são incorporadas." Assegura-se, no entanto, o direito de recesso dos acionistas dissidentes, tanto da sociedade incorporadora, quanto da incorporada.

Ao tratar da incorporação de ações, Modesto Carvalhosa sustenta que não se trata de incorporação propriamente dita, mas, sim, de uma expropriação e de uma alienação ficta. Nas palavras do autor:

Trata-se, o negócio de incorporação de ações, ao mesmo tempo de uma incorporação e de uma alienação fictas. No primeiro caso, porque não se incorpora uma sociedade em outra, na medida em que a incorporada subsiste como pessoa jurídica, (...). No segundo caso, porque o controlador da sociedade incorporada aliena não apenas as suas ações à incorporadora, mas também as dos minoritários, num negócio sui generis, que lembra a expropriação do direito administrativo. $^{53}$ (grifado no original)

Prossegue, o autor, explicando que na realidade não há qualquer incorporação na operação de incorporação de ações, pois um dos pressupostos da incorporação é a extinção de uma das companhias envolvidas na operação.

Discute-se, também, a possibilidade de aplicação do instituto da incorporação de ações a outros tipos societários, que não sejam a sociedade anônima. Tendo em vista que o artigo 252 da LSA falou apenas em incorporação das ações a outra "companhia" brasileira, defende-se que isso somente seria possível se a incorporadora também assumisse a forma de sociedade anônima ${ }^{54}$.

Em sentido contrário, Paulo Roberto Costa Figueiredo ${ }^{55}$ argumenta

\footnotetext{
${ }^{53}$ CARVAlHOSA, Modesto. Comentários à Lei de Sociedades Anônimas. $4^{\circ}$ vol. tomo II. $3^{\mathrm{a}}$ ed. São Paulo: Saraiva, 2009. p. 140 - 141.

${ }^{54}$ Nesse sentido se posicionam Nelson Eizirik, Egberto Lacerda Teixeira e José Alexandre T. Guerreiro, e Alfredo Lamy Filho e José Luiz Bulhões Pedreira. EIZIRIK, Nelson. A Lei das S/A Comentada. vol. III. São Paulo: Quartier Latin, 2011. p. 390; e GUERREIRO, José Alexandre T.; TEIXEIRA, Egberto Lacerda. Das sociedades anônimas no direito brasileiro. vol. 2. São Paulo: Bushatsky, 1979. p. 726, apud FIGUEIREDO, Paulo Roberto Costa. Subsidiaria integral: a sociedade unipessoal no direito brasileiro. São Paulo: Saraiva, 1984. p. 90; e FILHO, Alfredo Lamy; PEDREIRA, José Luiz Bulhões. Direito das Companhias. vol. II. $1^{\text {a }}$ ed. Rio de Janeiro: Forense, 2009. p. 1995.

55 FIGUEIREDO, Paulo Roberto Costa. Subsidiaria integral: a sociedade unipessoal no direito brasileiro. São Paulo: Saraiva, 1984. p. 90. No mesmo sentido, Modesto Carvalhosa. CARVALHOSA, Modesto. Comentários à Lei de Sociedades Anônimas. $4^{\circ}$ vol. tomo II. $3^{\mathrm{a}}$ ed. São Paulo: Saraiva, 2009. p. 144-145.
} 
que não haveria motivo para a lei permitir a constituição de subsidiária integral por outros tipos societários nos casos de constituição originária e de aquisição da totalidade das ações e proibir para o caso de incorporação de ações. Sustenta, o autor, que a interpretação literal da norma, nessa hipótese, afastaria o intérprete da verdadeira intenção do legislador.

Assim como o que ocorre na aquisição de ações, a incorporação se caracteriza como uma modalidade derivada de constituição da subsidiária integral, em oposição à modalidade originária. Nesta, a sociedade constituinte destaca parcela de seu patrimônio para constituir uma nova companhia, enquanto que naquelas há a conversão de uma companhia já existente em subsidiária integral.

No caso de reversão da subsidiária integral para sociedade pluripessoal, conforme previsto no artigo 253 da LSA, os acionistas da companhia controladora terão direito de preferência na aquisição das ações da subsidiária integral ou na subscrição de ações no aumento de capital da subsidiária integral. A referida norma pretende evitar que se utilize a conversão da companhia em subsidiária integral para lesar os direitos dos acionistas minoritários. Dessa forma, ela lhes assegura o direito de preferência que lhes foi negado quando da criação da subsidiária integral.

Além de ela ser a única forma admitida no ordenamento nacional de sociedade unipessoal constituída originariamente, o estudo das subsidiárias integrais se mostra especialmente relevante por representar a introdução da teoria institucionalista no direito brasileiro. A grande empresa, constituída sob a forma de sociedade anônima, foi concebida no Brasil sob a inspiração do institucionalismo dominante na Alemanha ${ }^{56}$, o que permitiu a disciplina da subsidiária integral sem grande choque com a teoria contratualista que rege as sociedades limitadas.

Cabe indagar, por fim, por que até 2011 o ordenamento brasileiro havia restringido as sociedades unipessoais às subsidiárias integrais. De

\footnotetext{
${ }^{56}$ FILHO, Calixto Salomão. A sociedade unipessoal. São Paulo: Malheiros, 1995. p. 55.
} 
acordo com Modesto Carvalhosa ${ }^{57}$, o motivo de tal restrição repousa no regime da publicidade aplicável às companhias e, por extensão, às subsidiárias integrais, o qual proporciona maior segurança aos credores, aos contratantes e aos acionistas da controladora. Os órgãos sociais da companhia na subsidiária integral teriam sido mantidos também por esse motivo.

A subsidiária integral representa um grande passo para a aceitação da unipessoalidade societária como forma de proteção do empresário individual. Ela demonstra que o direito brasileiro já lançou as bases para a introdução desse instituto. No entanto, suas características não permitem que ela seja usada com esse propósito. Mesmo que se admitisse a sua constituição por pessoa natural, a estrutura da sociedade anônima é muito complexa e dispendiosa para o comerciante individual comum.

Nesse sentido, questiona-se: se o direito brasileiro podia conviver com a sociedade unipessoal na forma da subsidiária integral, por que não poderia aceitá-la em outras modalidades societárias? Se bastavam apenas algumas regras sobre transparência e publicidade, por que não seria possível adaptar tais regras às sociedades limitadas?

A resposta para essas perguntas parece estar no apego ao formalismo e no conservadorismo. Como será visto adiante, mesmo com a introdução do novo instituto da Lei 12.441/2011 não nos desvencilhamos desses apegos.

\subsection{A unipessoalidade temporária}

A unipessoalidade superveniente é aquela que se produz depois da constituição da sociedade. Por vezes, mesmo a sociedade sendo constituída em observância a todos os requisitos legais, incluindo a pluralidade de sócios, o seu quadro societário pode se ver reduzido a apenas 01 (um) sócio.

\footnotetext{
${ }^{57}$ CARVAlHOSA, Modesto. Comentários à Lei de Sociedades Anônimas. $4^{\circ}$ vol. tomo II. $3^{\mathrm{a}}$ ed. São Paulo: Saraiva, 2009. p. 132.
} 
Essas são situações em que não há simulação nem fraude ao requisito da pluralidade social e tampouco irregularidade na constituição da sociedade.

Diversos motivos podem levar à concentração das ações ou quotas nas mãos de 01 (um) único sócio, tais como adversidades financeiras ou a morte do outro sócio. Para essas situações a lei prevê uma exceção: a possibilidade de a sociedade ou companhia se manterem regulares por determinado prazo ainda que apenas com 01 (um) sócio - é a chamada unipessoalidade temporária.

O princípio da preservação da empresa, que conquistou espaço na doutrina e na jurisprudência a partir de 1960, favoreceu a consolidação da dissolução parcial da sociedade nos casos elencados acima. Evitam-se, com isso, eventuais problemas como perda de empregos, desabastecimento do mercado e estremecimento das relações com credores ${ }^{58}$.

Segundo o Professor Haardt ${ }^{59}$, haveria 03 (três) correntes de política legislativa quando se trata da unipessoalidade temporária:

(...) na primeira, se incluiriam os países onde o legislador ou a jurisprudência se pronunciam no sentido de que a circunstância não exerce nenhuma influência sobre a subsistência válida da sociedade como pessoa jurídica; na segunda, encontram-se os países onde a circunstância não produz a dissolução da sociedade de pleno direito, encarada como uma situação temporária que, se não suprimida, prontamente, gerará consequências desagradáveis para a sociedade e seus acionistas; um terceiro grupo de países prevê que o fato provoca a dissolução imediata da sociedade e a perda da sua personalidade jurídica.

No Brasil, atualmente, a unipessoalidade temporária é aceita tanto na LSA, para as sociedades anônimas, quanto no CCB, para as sociedades limitadas, enquadrando-se no segundo grupo de países mencionado acima.

\subsubsection{Unipessoalidade temporária nas Sociedades Anônimas}

\footnotetext{
${ }^{58}$ COELHO, Fábio Ulhoa. Curso de Direito Comercial. $13^{\mathrm{a}}$ ed. São Paulo: Saraiva, 2009. v. 2. p. 475.

59 HAARDT, W. L. La société d'une seule personne. "Rapport Général” pronunciado no VII Congresso da Academia Internacional de Direito Comparado. Uppsala, 6 - 13 de agosto de 1966. Wassenar, julho de 1966, apud FIGUEIREDO, Paulo Roberto Costa. Subsidiaria integral: a sociedade unipessoal no direito brasileiro. São Paulo: Saraiva, 1984. p. 17-18.
} 
A unipessoalidade superveniente e temporária é aceita para as sociedades anônimas desde o Decreto 2.627/1940. Referido diploma legal exigia um mínimo de 07 (sete) acionistas para a constituição de uma sociedade anônima, mas permitia que ela permanecesse com número inferior até a assembleia geral ordinária seguinte àquela em que o evento foi constatado. Caso contrário, o artigo 137, d determinava a liquidação da companhia.

O artigo 80, I da LSA reduziu o número mínimo de acionistas a 02 (dois). Referido instrumento, no mesmo sentido que o anterior, admite a unipessoalidade temporária, prevendo a dissolução de pleno direito da companhia que não restaurar a pluralidade de acionistas no prazo fixado no artigo 206, I, d. Dessa forma, a lei permite à companhia manter a sua regularidade até a restauração da pluralidade de acionistas, que deverá ocorrer na assembleia geral ordinária seguinte àquela em que se verificou a redução do número de acionistas.

Dentre as causas de dissolução de pleno direito da companhia, além da unipessoalidade incidental já mencionada, estão o fim do prazo de duração da companhia, previsto no seu estatuto; outros casos previstos no estatuto social; a deliberação da assembleia geral; a extinção da autorização legal para seu funcionamento; eventual decisão judicial nesse sentido; e decisão por parte de autoridade administrativa competente. Vale observar que, ao tratar da unipessoalidade temporária como causa de dissolução, o artigo 206, I, d ressalva a hipótese de subsidiária integral prevista no artigo 251 da lei.

Paulo Roberto Costa Figueiredo ${ }^{60}$, no entanto, informa que em muitos ordenamentos jurídicos se estabeleceu que a não restauração da pluralidade no prazo não acarreta a dissolução de pleno direito. Esta só viria a ocorrer mediante a provocação de pessoas interessadas. Esse era o caso, por exemplo, de Portugal e da França.

\footnotetext{
${ }^{60}$ FIGUEIREDO, Paulo Roberto Costa. Subsidiaria integral: a sociedade unipessoal no direito brasileiro. São Paulo: Saraiva, 1984. p. 17.
} 
O autor critica, ainda, a previsão legal do momento em que se deve constatar a unipessoalidade. Ele defende que não haveria tamanha diferença entre a assembleia geral ordinária e a extraordinária, a não ser a época de realização e o quórum exigido para as ordinárias, o qual poderia vir ser observado por uma assembleia geral extraordinária. Ainda, o autor observa que se a intenção do legislador era instituir um prazo de 01 (um) ano para recomposição dos acionistas, a forma escolhida foi equivocada.

Diversos eventos poderiam levar o período de unipessoalidade a se estender por prazo superior ao de 01 (um) ano, tal como a saída de um acionista imediatamente após a realização de uma assembleia geral ordinária. Levaria até a assembleia do ano seguinte para tal fato ser verificado, concedendo-se prazo de mais 01 (um) ano para restauração da pluralidade, totalizando aproximadamente 02 (dois) anos de unipessoalidade.

Também se pode imaginar uma situação em que os acionistas não realizassem a assembleia geral ordinária no prazo legal, ou, simplesmente, não a realizassem naquele ano. Com isso, sequer haveria o momento previsto em lei para verificação da unipessoalidade e início da contagem do prazo.

A expressão "de pleno direito" utilizada pelo artigo 206, I, segundo Modesto Carvalhosa ${ }^{61}$, pode levar à noção equivocada de que a dissolução da companhia ocorreria automaticamente, independentemente de qualquer outro procedimento. Alfredo Lamy Filho e José Luiz Bulhões Pedreira ${ }^{62}$, contudo, defendem que tal interpretação não se sustenta. A expressão "de pleno direito" se referiria tão somente à produção dos efeitos da dissolução, produção esta que seria automática.

Não se trata, pois, da dissolução em si, mas apenas de seus efeitos, como, por exemplo, a submissão a regime jurídico especial, com a restrição

\footnotetext{
${ }^{61}$ CARVAlHOSA, Modesto. Comentários à Lei de Sociedades Anônimas. $4^{\circ}$ vol. tomo I. $4^{\mathrm{a}}$ ed. São Paulo: Saraiva, 2009. p. 39-40.

${ }^{62}$ FILHO, Alfredo Lamy; PEDREIRA, José Luiz Bulhões. Direito das Companhias. vol. II. $1^{\text {a }}$ ed. Rio de Janeiro: Forense, 2009. p. 1829.
} 
das atividades da companhia e o início do processo de liquidação do patrimônio. Assim, apenas após a extinção da companhia estaria completa a sua dissolução.

Nelson Eizirik ${ }^{63}$, diferentemente dos autores acima, leciona que a dissolução pode ser entendida de forma ampla ou estrita. Amplamente, a dissolução englobaria todos os eventos, desde a identificação da causa de dissolução, até a extinção e o término da personalidade jurídica da companhia. Já a noção estrita, divide os eventos que levam ao fim da companhia em 03 (três): dissolução, liquidação e extinção. A LSA teria adotado a dissolução estrita, pois prevê, no artigo 207, que a personalidade jurídica permanece existente até o momento da extinção, mesmo que a companhia já esteja dissolvida.

\subsubsection{Unipessoalidade temporária nas Sociedades Limitadas}

O Decreto 3.708/1919, que regulava as sociedades por quotas de responsabilidade limitada, sucedidas pelas sociedades limitadas, não elencava a unipessoalidade temporária como forma de dissolução da sociedade. Nas palavras de Paulo Roberto Costa Figueiredo ${ }^{64}$, "Muito provavelmente o silencio do Código Comercial deve-se àquele repúdio à unipessoalidade, que deve ter levado o legislador de 1850 e 1919 (Dec. $n$. 3.708) a considerar despiciendo prever que, uma vez verificada, dissolverse-ia a sociedade."

No entanto, o legislador de 2002 determinou, no artigo 1.033, IV do CCB, que a redução do número de sócios a 01 (um) ocasionará a dissolução da sociedade se a restauração da pluralidade não ocorrer em 180 (cento e oitenta dias). A dissolução da sociedade também não ocorrerá se, dentro do prazo previsto, o sócio remanescente requerer a transformação da sociedade

\footnotetext{
${ }^{63}$ EIZIRIK, Nelson. A Lei das S/A Comentada. vol. III. São Paulo: Quartier Latin, 2011. p. 142 143.

${ }^{64}$ FIGUEIREDO, Paulo Roberto Costa. Subsidiaria integral: a sociedade unipessoal no direito brasileiro. São Paulo: Saraiva, 1984. p. 24.
} 
limitada em empresário individual ou em EIRELI. Esta última possibilidade foi introduzida pela Lei 12.441/2011.

De acordo com Fábio Ulhoa Coelho ${ }^{65}$, "A jurisprudência passou a admitir a unipessoalidade temporária da limitada, como forma de contornar dificuldades operacionais derivadas da dissolução total da sociedade, e preservar a limitação da responsabilidade do empreendedor." $\mathrm{O}$ autor defende que os custos ocasionados pela dissolução total e imediata da sociedade são muito altos e, por isso, justificariam a concessão de prazo para que o sócio remanescente busque novo parceiro.

A dissolução parcial da sociedade limitada reduzida a 01 (um) sócio seria uma opção, no mínimo, mais econômica. Ela evitaria a obrigatoriedade da transformação da sociedade em empresário individual, com a consequente obrigação de atualizar os seus registros perante os órgãos competentes e necessidade de ceder os contratos de trabalho para a nova pessoa contratante.

Os 02 (dois) casos de unipessoalidade ora analisados constituem uma abertura para a admissão da unipessoalidade originária. Entretanto, mesmo diante disso e das facilidades que a sociedade unipessoal apresenta quando confrontada com os modelos não societários, o legislador brasileiro considerou melhor seguir por outro caminho. ${ }^{65}$ COELHO, Fábio Ulhoa. Curso de Direito Comercial. 13a ed. São Paulo: Saraiva, 2009. v. 1. p.
476. 


\section{A UNIPESSOALIDADE NO DIREITO COMPARADO}

Diferentemente da legislação pátria, há décadas o direito comparado nos concede diversos exemplos de ordenamentos jurídicos em que a limitação da responsabilidade do empresário individual é aceita, ora na forma de sociedade unipessoal, ora como um dos modelos não societários.

Em 1926, inspirado pelos estudos de Oscar Pisko, o Principado de Liechtenstein criou o primeiro modelo de patrimônio autônomo afetado à atividade comercial. ${ }^{66}$ A respeito do vanguardismo do Principado de Liechtenstein, a autora Wilges Ariana Bruscato $^{67}$ traz uma explicação concisa que consegue demonstrar com precisão as ideias incorporadas por esse Estado:

Em matéria de liberalismo, o Principado de Liechtenstein, que saiu na frente na limitação da responsabilidade do comerciante individual, adotando o modelo de Oscar Pisko, em vigor, pelos artigos 637 a 646 do PGR, é inigualável. Além de ser possível a criação de diversos tipos de pessoas jurídicas unipessoais, para sociedades de pessoa ou de capital, faculta-se a criação de qualquer outro modelo não previsto em lei, seguidas algumas condições básicas. (grifado no original)

Em 1989, impulsionada pelo exemplo de alguns estados europeus que já haviam introduzido a limitação da responsabilidade do empresário individual em suas legislações ${ }^{68}$, a Comunidade Europeia reconheceu, oficialmente, as implicações práticas de tal medida para a economia. Ainda sob a vigência da Comunidade Econômica Europeia (CEE), foi editada a $12^{\text {a }}$ Diretiva do Conselho (89/667/CEE) ${ }^{69}$, a qual determinava a todos os países membros da Comunidade Europeia a instituição da sociedade de responsabilidade limitada de 01 (um) único sócio. Exceção foi feita para os países onde já houvesse alguma forma de limitação da responsabilidade do

\footnotetext{
${ }^{66}$ FIGUEIREDO, Paulo Roberto Costa. Subsidiaria integral: a sociedade unipessoal no direito brasileiro. São Paulo: Saraiva, 1984. p. $56-61$.

${ }^{67}$ BRUSCATO, Wilges Ariana. Empresário Individual de Responsabilidade Limitada. São Paulo: Quartier Latin, 2005. p. 253.

${ }^{68}$ Tal era o caso, por exemplo, de Portugal e da França, como será analisado adiante, e do Principado de Liechtenstein, como já mencionado.

${ }^{69} 12^{\mathrm{a}}$ Diretiva do Conselho (89/667/CEE). Disponível em http://eur-lex.europa.eu/LexUriServ/ LexUriServ.do?uri=OJ:L:1989:395:0040:0042:PT:PDF. Acesso em 04 de abril de 2012.
} 
empresário individual, como era o caso de Portugal.

As diretrizes de tal norma eram claras: reconhecia-se a importância da criação de um instrumento jurídico que estimulasse novos empreendimentos dentro da seara das pequenas e médias empresas. Pretendia-se uniformizar a questão da unipessoalidade nos países europeus, pois, nessa época, o tratamento dispendido para as sociedades unipessoais se mostrava bastante diferente nos diversos países integrantes da Comunidade Europeia ${ }^{70}$. Vale observar, ainda, que a $12^{\text {a }}$ Diretiva se inseria dentro do programa de ação para as pequenas e médias empresas, adotado pelo Conselho em 03 de novembro de $1986^{71}$.

A $12^{a}$ Diretiva se aplica às sociedades de responsabilidade limitada ou às sociedades equivalentes a estas. Ela prevê que a unipessoalidade pode ser originária ou superveniente, estando a superveniência sujeita a regras sobre a publicidade de tal fato. A diretiva estabelece, ainda, algumas regras sobre a relação entre o sócio único e a sociedade: as suas decisões devem ser colocadas por escrito ou serem lavradas em ata, aplicando-se o mesmo aos eventuais contratos celebrados entre o sócio e a sociedade.

Abre-se espaço para a autonomia do direito interno de cada país para decidir sobre a possibilidade de sociedades unipessoais serem sócias de outras sociedades unipessoais, sobre a aplicação de tais regras às sociedades anônimas e sobre a dispensa de ata ou forma escrita para os negócios entre sócio e sociedade, quando se tratar, exclusivamente, das operações correntes desta.

Com o advento da União Europeia, a Diretiva 2009/102/CE ${ }^{72}$ do Parlamento e Conselho Europeu substituiu integralmente a $12^{\mathrm{a}}$ Diretiva, tendo sido aprovada em 16 de setembro de 2009 e publicada em 01 de

\footnotetext{
${ }^{70}$ CORDEIRO, António Menezes. Direito Europeu das Sociedades. Coimbra: Almedina, 2005. p. 475.

${ }^{71}$ Conforme se extrai do texto do próprio instrumento legal "Considerando que, pela sua resolução de 3 de Novembro de 1986, o Conselho adoptou, em 3 de Novembro de 1986, o programa de ação para as pequenas e médias empresas (PME) (...)". 12 $12^{\mathrm{a}}$ Diretiva do Conselho (89/667/CEE). Disponível em http://eur-lex.europa.eu/LexUriServ/LexUriServ.do?uri=OJ:L:1989:395:0040: 0042:PT:PDF. Acesso em 04 de abril de 2012.

72 Diretiva 2009/102/CE. Disponível em http://eur-lex.europa.eu/LexUriServ/LexUriServ. do?uri=OJ:L:2009:258:0020:0025:PT:PDF. Acesso em 04 de abril de 2012.
} 
outubro de 2009. O novo instrumento consolidou as modificações sofridas pelo anterior, principalmente no que se refere às adaptações para os países então membros da União Europeia e para os tipos societários peculiares a cada país.

\subsection{Do Direito Português}

Mesmo antes da edição da $12^{\mathrm{a}}$ Diretiva, Portugal já havia previsto em lei uma maneira própria de proteção do empresário individual através do estabelecimento individual de responsabilidade limitada, o EsIRL. No entanto, não satisfeito com os resultados da medida, o legislador português veio a instituir a sociedade unipessoal por quotas, voltada especialmente para a proteção e o desenvolvimento dos comerciantes individuais.

Os subcapítulos abaixo se destinam a analisar essas medidas instituídas pelo direito português.

\subsubsection{O Estabelecimento Individual de Responsabilidade Limitada}

Antes de criar a sociedade unipessoal por quotas, o direito português fez uso de outra medida para proteger o empresário individual. Em 1986, o Decreto-Lei $248^{73}$ instituiu o estabelecimento mercantil individual de responsabilidade limitada, ou EsIRL.

Em 1986 o legislador português ainda não estava preparado para admitir a sociedade unipessoal originária e, portanto, optou primeiro pela modalidade não societária de proteção do comerciante individual ${ }^{74}$. Na época, a criação do EsIRL foi alvo de inúmeras críticas ${ }^{75}$. No entanto,

\footnotetext{
${ }^{73}$ Decreto-Lei 248/1986. Disponível em http://www.igf.min-financas.pt/inflegal/bd_igf/bd_legis geral/Leg_geral_docs/DL 248 86.htm. Acesso em 10 de maio de 2012.

${ }^{74}$ COSTA, Ricardo Alberto Santos. A sociedade por quotas unipessoal no direito português. Coimbra: Almedina, 2002. p. 257-258.

${ }^{75}$ CORDEIRO, António Menezes. Direito Europeu das Sociedades. Coimbra: Almedina, 2005. p. 485 .
} 
António Menezes Cordeiro ${ }^{76}$ defende que o instituto foi "tecnicamente bem elaborado e representa um conjunto de aspectos interessantes (...)".

O Decreto-Lei 248/1986, em sua exposição de motivos, abordou os modelos instituídos pela França e pela Alemanha, que já haviam incorporado aos seus ordenamentos a sociedade limitada unipessoal. A exposição de motivos explica que o modelo societário foi descartado por fidelidade à ideia da natureza contratual da sociedade e porque "as contribuições doutrinais portuguesas sobre a regulamentação jurídica específica das sociedades de um único sócio são escassas."77 Assim, o EsIRL seria uma forma menos traumática do que a introdução da sociedade unipessoal originária ${ }^{78}$.

O legislador português também explicou, na exposição de motivos, porque não adotou o modelo da personalização de um novo ente: a empresa individual como nova pessoa jurídica representaria um processo mais complicado e artificial. O patrimônio de afetação seria um meio mais direto para atingir o mesmo objetivo.

Trata-se de um patrimônio especial que pode ser afetado pelo empresário para a sua atividade comercial. O EsIRL pode ser instituído por qualquer pessoa física que queira exercer uma atividade comercial e deve ser constituído por escritura pública. No entanto, o artigo $1^{\circ}, \mathrm{n}^{\circ} 3$ do Decreto-Lei 248/1986 limita a criação de 01 (um) EsIRL por pessoa.

O capital mínimo do EsIRL não pode ser inferior a $€ 5.000,00$ (cinco mil euros) e o artigo $3^{\circ}, n^{\circ} 4$ do decreto determina que o capital deve estar integralmente liberado para o estabelecimento quando da sua constituição. Ainda, o capital pode ser constituído em dinheiro ou em bens suscetíveis de penhora, devendo a parcela em dinheiro corresponder a, no mínimo, 2/3 (dois terços) do capital.

A inexatidão da declaração do capital que constitui o EsIRL pode

\footnotetext{
${ }^{76}$ CORDEIRO, António Menezes. Direito Europeu das Sociedades. Coimbra: Almedina, 2005. p. 485.

${ }^{77}$ Exposição de motivos do Decreto-Lei 248/1986. Disponível em http://www.igf.min-financas.pt/ inflegal/bd_igf/bd_legis_geral/Leg_geral_docs/DL_248_86.htm. Acesso em 10 de maio de 2012.

${ }^{78}$ FILHO, Calixto Salomão. A sociedade unipessoal. São Paulo: Malheiros, 1995. p. 31.
} 
acarretar a responsabilização do seu instituidor e o descumprimento da versão do capital mínimo para o EsIRL poderá levar à sua liquidação. O instituidor do EsIRL também pode ser responsabilizado caso ele venha a falir por uma causa relacionada à atividade exercida no EsIRL e se comprove que não foi respeitado o princípio da separação patrimonial.

A lei portuguesa prevê, ainda, que o patrimônio total do empresário responderá por todas as suas dívidas contraídas antes da publicação da constituição do EsIRL. Excetua-se o caso previsto no artigo $6^{\circ}$, última parte, segundo o qual o ato constitutivo do EsIRL será eficaz contra terceiros que tinham conhecimento dele quando seus direitos se originaram, ainda que antes da sua publicação.

O EsIRL pode ser transmitido por ato gratuito ou oneroso e pode ser objeto de locação, usufruto e penhor. Todos esses atos devem ser realizados sob a forma de escritura pública e estão sujeitos à obrigação de publicidade estabelecida no artigo $16^{\circ}, \mathrm{n}^{\circ} 2$, sob pena de nulidade do ato.

Não há, todavia, qualquer dispositivo que autorize a transmissão parcial do EsIRL, do que se depreende que o EsIRL só poderá ser transmitido em sua integralidade. Caso contrário, seria necessária a sua alteração para a forma societária ${ }^{79}$. Percebe-se, aí, uma dificuldade na circulação do patrimônio de afetação, característica do modelo não societário adotado.

A morte do seu titular ou a dissolução do seu casamento que acarrete o fim da comunhão de bens entre os cônjuges não causará a liquidação automática do EsIRL. Entretanto, a sua liquidação poderá ser requerida por qualquer interessado se, no prazo de 90 (noventa) dias da morte do titular ou do ato de separação, os herdeiros ou os cônjuges não acordarem sobre o destino do EsIRL.

Apesar da inovação que o EsIRL representou, ele obteve pouca receptividade na sociedade portuguesa e, "pode-se dizer com alguma

\footnotetext{
${ }^{79}$ FILHO, Calixto Salomão. A sociedade unipessoal. São Paulo: Malheiros, 1995. p. 34.
} 
segurança, que (...) não se implantou na prática empresarial" ${ }^{80}$, levando o legislador português a criar a SQU 10 (dez) anos depois.

\subsubsection{A sociedade unipessoal por quotas}

Em consonância com a tendência europeia, o direito português só veio a tutelar a unipessoalidade societária superveniente na segunda metade da década de $1940^{81}$. Esse quadro perdurou até o Decreto-Lei 257/1996 ${ }^{82}$, que instituiu a sociedade limitada unipessoal.

Antes do decreto, já existia a previsão no CSC da sociedade unipessoal superveniente sob o formato de sociedade por quotas. De acordo o artigo 84 do CSC, caso houvesse a falência da sociedade por quotas reduzida a 01 (um) único sócio, dadas certas condições, este sócio responderia ilimitadamente pelas obrigações da sociedade contraídas no período de concentração das quotas. A responsabilidade ilimitada do sócio único vigeria ainda que a pluralidade fosse restabelecida no prazo legal.

A esse respeito, Ricardo Alberto Santos Costa ${ }^{83}$ sustenta que a responsabilidade ilimitada do sócio só seria possível caso ele tivesse descumprido as regras previstas em lei para a separação patrimonial.

Também merece atenção o fato de que, decorrido o prazo legal para restauração da pluralidade societária, a dissolução da sociedade não se operava automaticamente. Ela somente ocorreria caso fosse requerida, por iniciativa de algum terceiro interessado.

Percebe-se, assim, que desde a promulgação do CSC português já se admitia a sociedade unipessoal, porém apenas de forma superveniente. $\mathrm{O}$ Decreto-Lei 257/1996, portanto, inovou quanto à possibilidade de

\footnotetext{
${ }^{80}$ COSTA, Ricardo Alberto Santos. A sociedade por quotas unipessoal no direito português. Coimbra: Almedina, 2002. p. 263.

${ }^{81}$ COSTA, Ricardo Alberto Santos. A sociedade por quotas unipessoal no direito português. Coimbra: Almedina, 2002. p. 240.

${ }^{82}$ Decreto-Lei 257/1996. Disponível em http://www.dgpj.mj.pt/sections/leis-da-justica/pdf-ult/declei-257-1996/downloadFile/file/DECLEI 257 1996.pdf?nocache=1184233598.88. Acesso em 04 de abril de 2012.

${ }^{83}$ COSTA, Ricardo Alberto Santos. A sociedade por quotas unipessoal no direito português. Coimbra: Almedina, 2002. p. 99.
} 
constituição originária da sociedade unipessoal, introduzindo os artigos $270^{\circ}-\mathrm{A}$ a $270^{\circ}-\mathrm{G}$ no $\mathrm{CSC}$.

Referido decreto trata da importância das sociedades unipessoais para o desenvolvimento de pequenas empresas, as quais constituiriam um fator de estabilidade e de criação de emprego, principalmente em época de crise, bem como de revitalização da atividade econômica, em geral, e da iniciativa privada, em particular.

Ao tratar do EsIRL e da importância da SQU, o decreto reconhece que

\begin{abstract}
A criação do estabelecimento individual de responsabilidade limitada pelo Decreto-Lei n. ${ }^{\circ}$ 248/86, de 25 de Agosto (sic), não atingiu esses resultados. Fiel à doutrina tradicional, o legislador de então não conseguiu ultrapassar a concepção contratualista da sociedade e por isso rejeitou qualquer concessão à concepção institucional. (...) Afastou-se expressamente das soluções já nessa altura adoptadas (sic) pela Alemanha e pela França. (...) Teve-se como indiscutível que a sociedade unipessoal não era instrumento apropriado à realidade do nosso país e daí enveredar-se por uma pretensa e difícil inovação. Negou-se personalização a algo que a reclamava. (...) Mas importa sobretudo facultar às pessoas uma forma de limitação da sua responsabilidade que não passe pela constituição de sociedades fictícias, com «sócios de favor», dando azo a situações pouco claras no tecido empresarial. ${ }^{84}$
\end{abstract}

O legislador português escolheu a sociedade por quotas, correspondente à sociedade limitada brasileira, para receber o instituto da sociedade unipessoal No entanto, ele não criou uma disciplina jurídica específica para a SQU, não instituindo regras especiais para a sua constituição, administração e relação com credores, por exemplo.

$\mathrm{O}$ artigo $270^{\circ}-\mathrm{G}$ do $\mathrm{CSC}$ determina que sejam aplicáveis à SQU as disposições referentes às sociedades por quotas que não pressuponham a pluralidade de sócios. Entende-se, portanto, que a SQU se rege pelas disposições da sociedade por quotas pluripessoal.

A SQU pode ser constituída originariamente ou derivar da concentração superveniente das quotas nas mãos de 01 (um) só sócio. No

\footnotetext{
${ }^{84}$ Decreto-Lei 257/1996. Disponível em http://www.dgpj.mj.pt/sections/leis-da-justica/pdf-ult/declei-257-1996/downloadFile/file/DECLEI 257_1996.pdf?nocache=1184233598.88. Acesso em 04 de abril de 2012.
} 
entanto, o sócio remanescente deve se manifestar sobre seu desejo de transformar a sociedade em SQU. Da mesma forma, ela pode ser resultado da transformação de um EsIRL em sociedade unipessoal.

O sócio único pode ser tanto pessoa física quanto pessoa jurídica, mas às pessoas físicas é vedada a constituição de mais de 01 (uma) SQU. Também se proíbe a constituição de uma SQU por outra sociedade unipessoal. $\mathrm{O}$ direito português adotou a faculdade concedida pela $12^{\mathrm{a}}$ Diretiva, segundo a qual não era obrigatória a autorização para a constituição de sociedades unipessoais por outras sociedades da mesma espécie.

A transformação da SQU em sociedade plural pode ser realizada por meio da divisão e cessão de quota ou de aumento de capital social. Nesse caso, deverá ser retirado do nome empresarial da sociedade a expressão "sociedade unipessoal" ou a palavra "unipessoal", expressões estas cuja presença é mandatória por força do artigo $270^{\circ}$-B do CSC.

As deliberações do sócio único, quando tiverem a natureza de deliberação de assembleia geral, devem assumir a forma de ata, a ser assinada pelo sócio. O sócio da SQU exercerá as competências das assembleias gerais. Além disso, os negócios jurídicos celebrados entre o sócio único e a SQU precisam assumir a forma escrita. Cabe ressaltar que o artigo $270^{\circ}-\mathrm{F}, \mathrm{n}^{\circ} 4$ prevê expressamente a responsabilidade ilimitada do sócio que violar as regras para contratação entre o sócio e a SQU.

Apenas a título de curiosidade, além da SQU prevista no CSC, o Decreto-Lei 500/1980 criou a Zona Franca da Madeira, que, atualmente, goza de um regime especial para as sociedades anônimas e as sociedades por quotas, instituído pelo Decreto-Lei 212/1994. As regras para essa zona especial diferem em alguns aspectos daquelas previstas como regra geral no CSC para a SQU.

Dentre eles há a instituição de um regime mais brando para a contratação entre o sócio único e a sociedade, a qual não dependerá de uma formalização adicional quando se tratar dos negócios correntes da 
sociedade. Também não se identifica, no regime especial da Zona Franca da Madeira, a proibição para que uma pessoa física possa constituir mais do que 01 (uma) SQU ${ }^{85}$.

Por fim, merece atenção especial a exposição de motivos do DecretoLei 257/1996, segundo o qual as mudanças instituídas por ele pretendiam modificar "disposições ultrapassadas e procedimentos desconformes com a realidade quotidiana do mundo empresarial" que persistiam na legislação comercial portuguesa.

\subsection{Do Direito Francês}

A França, tal como Portugal, adotou tanto a forma societária quanto a não societária para a limitação dos riscos do empresário singular. Anteriormente à $12^{\mathrm{a}}$ Diretiva, o legislador francês já havia entendido por bem proteger o empresário individual the possibilitando constituir, individualmente, uma sociedade limitada. Foi nesse intuito que a Lei 1985$697^{86}$ criou a enterprise unipersonnelle à responsabilité limitée.

Curiosamente, a Lei 1985-697 foi precedida de um estudo que concluiu pela superioridade do modelo não societário para a proteção patrimonial do comerciante. O projeto Champaud, denominado em homenagem ao Ministro da Justiça que presidiu a comissão em 1977, tinha como propósito estudar a melhor forma de se instituir na França a proteção ao comerciante individual ${ }^{87}$.

Sua proposta consistiu na criação de 03 (três) esferas patrimoniais diferentes: 01 (uma) exclusivamente para as atividades comerciais; 01 (uma) que não se destinava unicamente às atividades comerciais, mas que poderia vir a ser utilizada nesse sentido se os credores não conseguissem ter seus créditos satisfeitos na primeira esfera; e 01 (uma) voltada somente para

\footnotetext{
${ }^{85}$ COSTA, Ricardo Alberto Santos. A sociedade por quotas unipessoal no direito português. Coimbra: Almedina, 2002. p. 303. Notas de rodapé n 279 e 280.

${ }^{86}$ Lei 1985-697, de 11 de julho de 1985. Disponível em http://legifrance.gouv.fr/affich Texte.do?cidTexte=JORFTEXT000000693457. Acesso em 10 de maio de 2012.

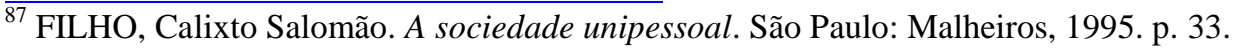


as dívidas civis do empresário e da sua família. A terceira esfera patrimonial corresponderia ao patrimônio mínimo do empresário necessário à sua sobrevivência e, por isso, seria indisponível e intangível ${ }^{88}$.

Recentemente, o ordenamento jurídico da França sofreu uma nova modificação com o objetivo de dar mais uma ferramenta para o comerciante singular. A Lei 2010-658 ${ }^{89}$ criou o entrepreneur individuel à responsabilité limitée, utilizando-se da técnica do patrimônio de afetação para criar um instituto similar ao português de 1986 .

Os subcapítulos abaixo pretendem analisar essas medidas e a opção do legislador francês.

\subsubsection{Enterprise Unipersonnelle à Responsabilité Limitée}

A doutrina jurídica francesa, historicamente, ofereceu resistência à aceitação da unipessoalidade societária ${ }^{90}$. Antes de 1985 , a Lei 1966-537 ${ }^{91}$, lei que promoveu uma ampla reforma das sociedades comerciais, não admitia a unipessoalidade originária, apenas tolerando a unipessoalidade superveniente.

$\mathrm{O}$ artigo $9^{\circ}$ do referido diploma legal previa que a concentração de todas as quotas nas mãos de 01 (um) único sócio não acarretava a dissolução de pleno direito da sociedade. Esta poderia ser requerida por qualquer interessado caso a pluralidade societária não fosse reconstituída no prazo legal de 01 (um) ano.

A admissão da unipessoalidade superveniente e temporária foi, por si só, um grande passo para o ordenamento jurídico francês. A legislação

\footnotetext{
${ }^{88}$ FILHO, Calixto Salomão. A sociedade unipessoal. São Paulo: Malheiros, 1995. p. 33.

${ }^{89}$ Lei 2010-658, de 15 de junho de 2010. Disponível em http://www.legifrance.gouv.fr/affich Texte.do;jsessionid=A3BBD58C28C53F8EEE226DCE33A954E1.tpdjo13v _ 1?cidTexte=JORFTE XT000022355229\&dateTexte $=20100616$. Acesso em 10 de maio de 2012.

90 COSTA, Ricardo Alberto Santos. A sociedade por quotas unipessoal no direito português. Coimbra: Almedina, 2002. p. 314.

${ }^{91}$ Lei 1966-537, de 24 de julho de 1966. Disponível em http://www.legifrance.gouv.fr/affich Texte.do jsessionid=722F6C839A5CECA8174DA525FF828654.tpdjo02v_1?cidTexte=JORFTEX $\underline{T} 000000692245 \&$ dateTexte $=20001231$. Acesso em 10 de maio de 2012.
} 
francesa se ateve durante muito tempo à concepção clássica de sociedade ${ }^{92}$. O antigo artigo 1.832 do código civil francês previa que sociedade era um contrato, a ser celebrado por 01 (uma) ou mais pessoas reunidas com um objetivo em comum. As sociedades que se tornassem unipessoais seriam dissolvidas de pleno direito.

No entanto, mesmo antes de 1985 já havia, na França, "uma corrente legislativa sensível à problemática da responsabilidade ilimitada do empresário individual" ${ }^{93}$. No entanto, os projetos existentes anteriormente a esse respeito pareciam aproximar-se mais das técnicas de separação patrimonial do que de uma sociedade unipessoal originária ${ }^{94}$.

Com a Lei 1985-697, adotou-se a forma societária para a limitação da responsabilidade do empresário individual, instituindo a enterprise unipersonnelle à responsabilité limitée, comumente denominada de EURL. Cabe observar que essa lei foi editada antes da $12^{\mathrm{a}}$ Diretiva.

A EURL somente pode ser constituída sob a forma de SARL société à responsabilité limitée, correspondente à sociedade limitada brasileira. A admissão da EURL, na França, representou a consagração da teoria institucionalista naquele país ${ }^{95}$.

Em decorrência da alteração de 1985, o artigo 1.832 do código francês passou a trazer previsão de que a SARL é instituída por 02 (duas) ou mais pessoas, podendo, nos casos previstos em lei, ser instituída pelo ato de vontade de 01 (uma) única pessoa. No mesmo sentido, modificou-se a Lei 1966-537 para possibilitar a criação de uma SARL por 01 (uma) ou mais pessoas. Percebe-se, com isso, que o legislador não criou uma nova espécie de sociedade dentro do gênero sociedade limitada. Apenas

\footnotetext{
${ }^{92}$ DAIGRE, Jean-Jacques. La société unipersonnelle. Revue internationale de droit comparé. Paris, Société de Législation Comparée, v. 42, n. 2, 1990.

${ }^{93}$ FIGUEIREDO, Paulo Roberto Costa. Subsidiaria integral: a sociedade unipessoal no direito brasileiro. São Paulo: Saraiva, 1984. p. 47.

${ }^{94}$ DAIGRE, Jean-Jacques. La société unipersonnelle. Revue internationale de droit comparé. Paris, Société de Législation Comparée, v. 42, n. 2, 1990.

${ }^{95}$ ISFER, Edson. Sociedades unipessoais e empresas individuais - responsabilidade limitada. Curitiba: Juruá, 1996. p. 128.
} 
modificou o regime jurídico antes vigente para a SARL ${ }^{96}$.

Em princípio, as mesmas regras de constituição aplicáveis à SARL regem a EURL. Ela pode ser originária ou superveniente, resultante da concentração de todas as quotas nas mãos do associé unique, bastando, para tal, uma alteração dos atos constitutivos da sociedade.

$\mathrm{Na}$ mesma linha adotada por Portugal, permite-se a instituição de EURL tanto por pessoas físicas quanto por pessoas jurídicas. Vedava-se, apenas, que as pessoas físicas constituíssem mais de 01 (uma) EURL e que uma EURL figurasse como sócia única de outra EURL. No entanto, a Lei $1994-126^{97}$ retirou essa limitação para as pessoas naturais.

$\mathrm{O}$ artigo L223-1 do $\mathrm{CCom}^{98}$ concede ao sócio único os poderes de que goza a assembleia de sócios das sociedades pluripessoais. Ele exercerá sozinho todos os atos que dependeriam da aprovação dos sócios na SARL. Além disso, a administração da EURL segue as mesmas regras básicas para as SARL, permitindo-se que o próprio sócio único, se ele for pessoa física, ou que um terceiro seja nomeado administrador. Não se admite a administração por pessoa jurídica.

No que se refere à contratação entre o sócio único e a EURL, o artigo L223-19, alínea 4 do CCom prevê a responsabilização do sócio que contrata com a sociedade pelos prejuízos a ela causados, salvo nos casos de operações correntes da sociedade concluídas em condições normais.

A respeito do capital social da EURL, a lei francesa exigia para as SARL um capital social mínimo de F 50.000,00 (cinquenta mil francos), ou $€ 7.500,00$ (sete mil e quinhentos euros). Adicionalmente, segundo o artigo L223-7 do CCom, o capital social subscrito em espécie deveria estar 20\% (vinte por cento) integralizado quando da constituição da sociedade, assim como a totalidade do capital social subscrito em bens. A integralização do

\footnotetext{
${ }^{96}$ DAIGRE, Jean-Jacques. La société unipersonnelle. Revue internationale de droit comparé. Paris, Société de Législation Comparée, v. 42, n. 2, 1990.

${ }^{97}$ Lei 1994-126, de 11 de fevereiro de 1994. Disponível em http://www.legifrance.gouv.fr/affich Texte.do? cidTexte=JORFTEXT000000165840\&dateTexte $=$. Acesso em 10 de maio de 2012.

98 Code de Commerce francês. Disponível em http://www.legifrance.gouv.fr/affichCode. do;jsessionid=37405AD6C56F4A5E65A8183D37AB5735.tpdjo14v 2?cidTexte=LEGITEXT000 $005634379 \&$ dateTexte $=20120510$. Acesso em 10 de maio de 2012.
} 
restante do capital social deveria ocorrer no prazo de 05 (cinco) anos contados do registro da sociedade. Como o EURL possui a natureza de uma SARL, diferindo-se apenas pela ausência da pluralidade de sócios, a mesma exigência se aplicava à EURL.

Atualmente, o ordenamento francês não possui mais essa exigência de capital mínimo. A Lei $2003-721^{99}$, que suprimiu o capital mínimo para a EURL, foi promulgada com o intuito de impulsionar a economia. Permanece, todavia, a exigência de integralização inicial de parcela do capital da sociedade.

O mesmo instrumento normativo de 1985 criou outra modalidade de sociedade unipessoal, a sociedade constituída para exploração agrícola, denominada exploitation agricole à responsabilité limitée ${ }^{100}$. Tal modalidade, no entanto, não será analisada aqui por não ser objeto do presente estudo.

Por fim, o ordenamento francês possui mais uma peculiaridade no que se refere à unipessoalidade societária, a société par actions simplifiée unipersonnelle, apelidada de SASU. Trata-se da forma unipessoal do modelo de sociedade anônima simplificada existente na França. Todavia, apesar de as sociedades anônimas simplificadas serem um tema de grande interesse, por não se tratar do objeto do presente estudo elas não serão analisadas aqui.

\subsubsection{Entrepreneur Individuel à Responsabilité Limitée}

Recentemente, a Lei 2010-658, promulgada em 15 de junho de 2010 e com vigência a partir de 01 de janeiro de 2011, criou o entrepreneur individuel à responsabilité limitée, ou EnIRL. O instituto é uma alternativa para o empresário individual que não deseja constituir uma sociedade, pois

\footnotetext{
${ }^{99}$ Lei 2003-721, de 01 de agosto de 2003. Disponível em http://www.legifrance.gouv.fr/affich Texte.do?cidTexte=LEGITEXT000005634924. Acesso em 10 de maio de 2012.

${ }^{100}$ ISFER, Edson. Sociedades unipessoais e empresas individuais - responsabilidade limitada. Curitiba: Juruá, 1996. p. 169.
} 
ele se utiliza da técnica do patrimônio de afetação. Preserva-se a qualidade de pessoa física do empresário visto que não há a criação de uma pessoa jurídica.

Percebe-se que a França optou pelo caminho inverso daquele seguido por Portugal, instituindo o EURL antes do EnIRL. O novo instituto se justificou pelo fato de a EURL ter obtido pouco sucesso no meio empresarial francês, representando apenas aproximadamente 6\% (seis por cento) do total das empresas em 2008, enquanto que os empresários individuais representavam a metade dessa cifra ${ }^{101}$.

O artigo L526-6, alínea 1 do CCom prevê que o patrimônio de afetação se compõe do conjunto de bens, direitos, obrigações e garantias dos quais o empresário é titular, necessários ao exercício da sua atividade empresarial e afetados por ele a essa atividade. Para exercer a atividade à qual o patrimônio foi afetado o empresário individual deverá adicionar ao seu nome a expressão "entrepreneur individuel à responsabilité limitée" ou a inicial "EIRL".

O empresário individual poderá optar pelo regime do EnIRL por meio de uma declaração de seu patrimônio profissional perante o registro empresarial competente. Da declaração deverá constar uma lista descritiva dos bens, direitos, obrigações e garantias afetados, bem como a menção da atividade profissional para a qual se institui o EnIRL.

A lei também autoriza, no artigo L526-9, alínea 3 do CCom, que o comerciante complemente a declaração de afetação anterior na eventualidade de desejar adicionar um novo bem ao patrimônio profissional.

A proteção conferida pelo EnIRL, no entanto, não é absoluta. O CCom prevê diversas hipóteses de responsabilização do empresário. A avaliação patrimonial incorreta do bem conferido ao patrimônio de afetação poderá levar à responsabilidade ilimitada do empresário individual, até o

\footnotetext{
${ }^{101}$ Informação obtida em apresentação denominada L'EIRL: Un nouveau statut juridique et fiscal pour l'entrepreneur. Disponível em http://www.eirl.fr/multimedia/diaporamas. Acesso em $10 \mathrm{de}$ maio de 2012.
} 
limite do montante superestimado do valor do bem. O artigo L526-10, alínea 3 do CCom estabelece o prazo de 05 (cinco) anos durante o qual o comerciante responderá com a integralidade do seu patrimônio civil e comercial pela quantia supervalorizada.

No mesmo sentido, o artigo L526-11, alínea $3 \mathrm{CCom}^{102}$ prevê a inoponibilidade da afetação do patrimônio perante terceiros no caso de não se seguir as regras previstas nesse mesmo artigo. A responsabilidade do instituidor também será ilimitada na hipótese de fraude ou falta grave no cumprimento das regras previstas no artigo L526-6, alínea $2^{103}$ e das obrigações previstas no artigo L526-13 do $\mathrm{CCom}^{104}$.

\footnotetext{
${ }^{102}$ Artigo L526-11 do CCom: "Lorsque tout ou partie des biens affectés sont des biens communs ou indivis, l'entrepreneur individuel justifie de l'accord exprès de son conjoint ou de ses coïndivisaires et de leur information préalable sur les droits des créanciers mentionnés au $1^{\circ}$ de l'article L. 526-12 sur le patrimoine affecté. Un même bien commun ou indivis ou une même partie d'un bien immobilier commun ou indivis ne peut entrer dans la composition que d'un seul patrimoine affecté. Lorsque l'affectation d'un bien commun ou indivis est postérieure à la constitution du patrimoine affecté, elle donne lieu au dépôt d'une déclaration complémentaire au registre auquel a été effectué le dépôt de la déclaration prévue à l'article L. 526-7. L'article L. 526-8 est applicable, à l'exception des $1^{\circ}$ et $2^{\circ}$. Le non-respect des règles prévues au présent article entraine l'inopposabilité de l'affectation." Disponível em http://www.legifrance.gouv.fr/ affichCode.do;jsessionid=994A0B6146504893FFE5BA251EF2DF42.tpdjo02v_1?idSectionTA=L EGISCTA000022356993\&cidTexte $=$ LEGITEXT000005634379\&dateTexte $=20120528 . \quad$ Acesso em 10 de maio de 2012.

103 Artigo L526-6 do CCom: "Tout entrepreneur individuel peut affecter à son activité professionnelle un patrimoine séparé de son patrimoine personnel, sans création d'une personne morale. Ce patrimoine est composé de l'ensemble des biens, droits, obligations ou sûretés dont l'entrepreneur individuel est titulaire, nécessaires à l'exercice de son activité professionnelle. Il peut comprendre également les biens, droits, obligations ou sûretés dont l'entrepreneur individuel est titulaire, utilisés pour l'exercice de son activité professionnelle et qu'il décide d'y affecter. Un même bien, droit, obligation ou sûreté ne peut entrer dans la composition que d'un seul patrimoine affecté. Par dérogation à l'alinéa précédent, l'entrepreneur individuel exerçant une activité agricole au sens de l'article L. 311-1 du code rural et de la pêche maritime peut ne pas affecter les terres utilisées pour l'exercice de son exploitation à son activité professionnelle. Cette faculté s'applique à la totalité des terres dont l'exploitant est propriétaire. Pour l'exercice de l'activité professionnelle à laquelle le patrimoine est affecté, l'entrepreneur individuel utilise une dénomination incorporant son nom, précédé ou suivi immédiatement des mots : 'Entrepreneur individuel à responsabilité limitée' ou des initiales: 'EIRL'." Disponível em http://www.legifrance.gouv.fr/affichCode.do;jsessionid=994A0B6146504893FFE5BA251EF2DF4 2.tpdjo02v_1?idSectionTA=LEGISCTA000022356993\&cidTexte=LEGITEXT000005634379\&da teTexte $=20120528$. Acesso em 10 de maio de 2012.

${ }_{104}$ Artigo L526-13 do Ccom: "L'activité professionnelle à laquelle le patrimoine est affecté fait l'objet d'une comptabilité autonome, établie dans les conditions définies aux articles L. 123-12 à L. 123-23 et L. 123-25 à L. 123-27. Par dérogation à l'article L. 123-28 et au premier alinéa du présent article, l'activité professionnelle des personnes bénéficiant des régimes définis aux articles 50-0, 64 et 102 ter du code général des impôts fait l'objet d'obligations comptables simplifiées. L'entrepreneur individuel à responsabilité limitée est tenu de faire ouvrir dans un établissement de crédit un ou plusieurs comptes bancaires exclusivement dédiés à l'activité à laquelle le patrimoine a été affecté." Disponível em http://www.legifrance.gouv.fr/affichCode.do;jsessionid=994A0B 6146504893FFE5BA251EF2DF42.tpdjo02v 1 1?idSectionTA=LEGISCTA000022356993\&cidText e=LEGITEXT000005634379\&dateTexte $=20120528$. Acesso em 10 de maio de 2012.
} 
Ainda, em caso de insuficiência do patrimônio de afetação, os credores do EnIRL anteriores ao depósito da declaração de afetação poderão exercer suas garantias contra o lucro obtido pelo EnIRL no exercício anterior. Os efeitos da declaração de afetação cessarão com a renúncia, a morte ou o fim da atividade profissional do EnIRL.

Quanto à transmissão do patrimônio de afetação, o artigo L526,-17 do CCom permite a cessão a título oneroso, a transferência a título gratuito e o aporte em sociedade da integralidade do patrimônio afetado sem que seja necessária a sua liquidação.

Por fim, apenas a título de curiosidade, a Lei 2003-721 também criou a déclaration de insaisissabilité, uma declaração de intangibilidade do imóvel onde se localiza a residência principal de uma pessoa física. A declaração também pode recair sobre outros bens imobilizados que não estejam ligados à atividade profissional da pessoa física. Os bens objeto da declaração se tornam intangíveis para os credores da atividade empresarial. A intangibilidade tem fim com a morte do empresário, a renúncia por ele ou a partilha dos bens depois do divórcio, caso a residência não permaneça com o empresário. 


\section{EMPRESA INDIVIDUAL DE RESPONSABILIDADE LIMITADA - EIRELI}

Recentemente, a Lei 12.441, aprovada em 11 de julho de 2011 e publicada no Diário Oficial da União no dia seguinte ${ }^{105}$, instituiu a empresa individual de responsabilidade limitada, ou apenas EIRELI. Ao introduzir algumas mudanças no $\mathrm{CCB}$, finalmente, o legislador pátrio trouxe para o nosso ordenamento a figura da limitação da responsabilidade do empresário individual.

Como se viu, antes de 2011 o direito brasileiro não contemplava a possibilidade de um indivíduo exercer a atividade empresarial com a mesma proteção conferida aos sócios e acionistas de sociedades empresárias - a limitação da sua responsabilidade patrimonial. Para que uma pessoa natural pudesse empreender sem arriscar o seu patrimônio particular, fazia-se necessária a constituição das chamadas "sociedades fictícias", "sociedades aparentes" ou "sociedades simuladas", cujos problemas já foram abordados.

A partir de janeiro de 2012, quando a nova lei entrou em vigor, o comerciante deixou de precisar recorrer a tais artifícios. Em que pesem as numerosas críticas ao instituto criado, a EIRELI foi bem-vinda pelos empresários, que poderão utilizar o instituto para se lançar em empreendimentos comerciais com mais segurança, sem pôr em risco seu patrimônio pessoal e aquele de sua família.

Essa receptividade pode ser percebida ao se observar que apenas nos poucos meses em que a lei esteve em vigor, foram instituídas 2.381 (duas mil, trezentas e oitenta e uma) ${ }^{106}$ EIRELI's na JUCESP ${ }^{107}$. Nem mesmo os

\footnotetext{
${ }^{105}$ Lei 12.441 , de 11 de julho de 2011. Disponível em http://www.planalto.gov.br/ccivil_03/_Ato 2011-2014/2011/Lei/L12441.htm. Acesso 08 de abril de 2012.

${ }^{106}$ A cifra engloba tanto as EIRELI's constituídas originariamente quanto aquelas resultantes de transformação societária. Informação obtida no site da JUCESP. Disponível em http://www.jucesp online.sp.gov.br/ResultadoBusca.aspx?IDProduto=\#i1jffS46G6Q\%3d. Acesso em 08 de abril de 2012.

${ }^{107}$ Em menor número, a JUCERJA indica a constituição de apenas 265 (duzentas e sessenta e cinco) EIRELI's, tanto instituídas originariamente quanto resultantes de transformação societária.
} 
questionamentos que rondam a EIRELI nem as críticas que vêm sido feitas pela comunidade jurídica afastaram os empresários dessa nova solução.

Todavia, referido número não convence de que a estrutura adotada pelo legislador nacional é a melhor opção, nem que a Lei 12.441/2011 irá, efetivamente, suprir a demanda dos comerciantes individuais. Passamos, então, a descrever a Lei 12.441/2011 de modo objetivo para, em seguida, analisar as principais críticas que ela tem recebido.

\subsection{A Lei 12.441/2011}

Primeiramente, inseriu-se no artigo 44 do CCB um novo inciso, pela qual as empresas individuais de responsabilidade limitada passaram a constituir nova modalidade de pessoa jurídica ${ }^{108}$. Em seguida, foi adicionado o Título I-A ao Livro II - Do Direito de Empresa do CCB, com a seguinte redação:

\section{TÍTULO I-A \\ DA EMPRESA INDIVIDUAL DE RESPONSABILIDADE LIMITADA}

Art. 980-A. A empresa individual de responsabilidade limitada será constituída por uma única pessoa titular da totalidade do capital social, devidamente integralizado, que não será inferior a 100 (cem) vezes o maior salário-mínimo vigente no País.

$\S 1^{\circ} \mathrm{O}$ nome empresarial deverá ser formado pela inclusão da expressão "EIRELI" após a firma ou a denominação social da empresa individual de responsabilidade limitada.

$\S 2^{\circ}$ A pessoa natural que constituir empresa individual de responsabilidade limitada somente poderá figurar em uma única empresa dessa modalidade.

$\S 3^{\circ} \mathrm{A}$ empresa individual de responsabilidade limitada também poderá resultar da concentração das quotas de outra modalidade societária num único sócio, independentemente das razões que motivaram tal concentração.

$\S 4^{\circ}$ (VETADO).

$\S 5^{\circ}$ Poderá ser atribuída à empresa individual de responsabilidade limitada constituída para a prestação de serviços de qualquer natureza a remuneração decorrente da cessão de direitos patrimoniais de autor ou de imagem, nome, marca ou voz de que seja detentor o titular da pessoa jurídica, vinculados à atividade profissional.

$\S 6^{\circ}$ Aplicam-se à empresa individual de responsabilidade limitada, no que

Disponível em http://www.jucerja.rj.gov.br/Servicos/Estatistica/nova /simples.asp?tp=1\& ano $=2012$. Acesso em 08 de abril de 2012.

${ }^{108}$ Artigo 44 da Lei 10.406/2002: “Art. 44. São pessoas jurídicas de direito privado: I - as associações; II - as sociedades; III - as fundações; IV - as organizações religiosas; V - os partidos políticos; VI - as empresas individuais de responsabilidade limitada." 
couber, as regras previstas para as sociedades limitadas.

Adicionalmente, a Lei 12.441/2011 modificou o parágrafo único do artigo 1.033 do $\mathrm{CCB}^{109}$ para incluir nova exceção à regra da dissolução da sociedade limitada pela falta de pluralidade de sócios: a sua transformação em EIRELI.

Por fim, o artigo $3^{\circ}$ da Lei 12.441/2011 determinou uma vacatio legis de 180 (cento e oitenta) dias a contar da data de sua publicação.

\subsubsection{Modelo adotado}

A partir da leitura dos dispositivos acima, observa-se que o legislador brasileiro optou pela personalização da empresa ao invés da criação da sociedade unipessoal de responsabilidade limitada ou do patrimônio de afetação do empresário individual. No entanto, embora tenha preferido outro modelo, a Lei 12.441/2011 limitou-se a se reportar às regras previstas para as sociedades limitadas ao invés de estabelecer regras próprias à EIRELI.

Percebe-se que o texto aprovado pelo Congresso Nacional em muito se afastou da proposta inicial, consubstanciada no Projeto de Lei 4.605/2009, de autoria do Deputado Marcos Montes - DEM/MG, e no Projeto de Lei 4.953/2009, de autoria do Deputado Eduardo Sciarra DEM/PR.

O Projeto de Lei 4.605/2009 previa a constituição de um novo tipo societário, a sociedade unipessoal. Apesar da nomenclatura utilizada,

\footnotetext{
${ }^{109}$ Artigo 1.033 da Lei 10.406/2002: “Art. 1.033. Dissolve-se a sociedade quando ocorrer: I - o vencimento do prazo de duração, salvo se, vencido este e sem oposição de sócio, não entrar a sociedade em liquidação, caso em que se prorrogará por tempo indeterminado; II - o consenso unânime dos sócios; III - a deliberação dos sócios, por maioria absoluta, na sociedade de prazo indeterminado; IV - a falta de pluralidade de sócios, não reconstituída no prazo de cento e oitenta dias; V - a extinção, na forma da lei, de autorização para funcionar. Parágrafo único. Não se aplica o disposto no inciso IV caso o sócio remanescente, inclusive na hipótese de concentração de todas as cotas da sociedade sob sua titularidade, requeira, no Registro Público de Empresas Mercantis, a transformação do registro da sociedade para empresário individual ou para empresa individual de responsabilidade limitada, observado, no que couber, o disposto nos arts. 1.113 a 1.115 deste Código."
} 
"empresa individual de responsabilidade limitada", a proposta pretendia adicionar mais 01 (um) tipo às modalidades de sociedades empresárias. Além de fazer referência aos termos "sócio", "capital social", "outra modalidade societária", "razão social" e "patrimônio social", fazendo alusão à natureza societária desse novo modelo, a justificação da proposta menciona expressamente a intenção de se criar uma sociedade unipessoal $^{110}$.

Esse projeto trazia vedação expressa quanto à constituição da EIRELI por pessoa jurídica. Somente pessoas naturais estariam autorizadas a constituir o novo modelo de sociedade e cada pessoa só poderia figurar como tal em 01 (uma) sociedade unipessoal.

O Projeto de Lei 4.953/2009, por sua vez, pretendeu instituir o empreendimento individual de responsabilidade limitada. Como ocorre com a EIRELI, o Deputado Eduardo Sciarra propôs a criação de uma nova modalidade de pessoa jurídica. Seu projeto previa a personalização de uma parcela dos bens do empresário individual, a qual passaria a constituir o empreendimento individual.

Além disso, o Projeto de Lei 4.953/2009 restringiu a constituição da nova pessoa jurídica à pessoa física, a qual só poderia ser titular de 01 (um) único empreendimento individual. Ele também trouxe uma extensa regulamentação a respeito da forma de constituição, do capital, da administração, da responsabilidade do titular do empreendimento, da prestação de contas, da remuneração do administrador e da dissolução e liquidação do empreendimento individual.

Cabe ressaltar, ainda, que o texto desse projeto evitou as confusões de nomenclatura em que incorreu a lei instituidora da EIRELI, não fazendo uso dos termos tipicamente utilizados para sociedades.

Durante a tramitação dos projetos, o Projeto de Lei 4.953/2009 foi

\footnotetext{
110 "Para justificar a importância de apresentarmos o presente projeto de lei, que tem o objetivo de instituir legalmente a 'Sociedade Unipessoal', também conhecida e tratada na doutrina como ‘Empresa Individual de Responsabilidade Limitada' (...)”. Projeto de Lei 4.605/2009. Disponível em http://www2.camara.gov.br/. Acesso em 08 de abril de 2012.
} 
apensado ao Projeto de Lei 4.605/2009. Submetidos, à Comissão de Desenvolvimento Econômico, Indústria e Comércio, esta optou pelo projeto do Deputado Marcos Montes, pois entendeu que ele contemplava as proposições do projeto do Deputado Eduardo Sciarra, apresentando um substitutivo com poucas modificações. Submetidos, então, à Comissão de Constituição e Justiça e de Cidadania, ela também aprovou as medidas, apresentando, por sua vez, um substitutivo próprio, que veio a se tornar a Lei 12.441/2011.

Foi com a nova redação proposta pela Comissão de Constituição e Justiça e de Cidadania que a EIRELI tomou a sua forma atual. Propôs-se a modificação dos artigos 44 e 1.033 do CCB e a criação do novo Título. Dessa forma, apesar de a proposta do Deputado Marcos Montes ter contemplado novo modelo societário, a EIRELI passou a integrar uma modalidade diferente de pessoa jurídica, descaracterizando-se por completo o objetivo inicial.

Em seguida, tentou-se descaracterizar os outros dispositivos que transpareciam a natureza societária do tipo proposto, fazendo-se alterações ao texto do Deputado Marcos Montes para adequá-lo ao que parece ser a proposta do Deputado Eduardo Sciarra. Ainda, o substitutivo introduziu a exigência de capital mínimo para a EIRELI, indexando-o ao salário mínimo vigente no país.

Objetivamente, Comissão de Constituição e Justiça e de Cidadania aproveitou a forma proposta pelo Deputado Marcos Montes para adaptá-la às ideias, à essência da proposta do Deputado Eduardo Sciarra. Disso resultou a nossa EIRELI, um misto da regulamentação sucinta dispendida a uma sociedade unipessoal, com a complexidade teórica demandada pela criação de uma nova pessoa jurídica.

\subsubsection{O veto presidencial}

A Presidente Dilma Rousseff vetou parcialmente o Projeto de Lei 
18/2011 (projeto 4.605/2009 na Câmara dos Deputados) por contrariedade ao interesse público. O artigo 980-A, $\S 4^{\circ}$ da Lei 10.406/2002, inserido pelo $\operatorname{artigo~} 2^{\circ}$ do referido projeto de lei, traria a seguinte redação:

$\S 4^{\circ}$ Somente o patrimônio social da empresa responderá pelas dívidas da empresa individual de responsabilidade limitada, não se confundindo em qualquer situação com o patrimônio da pessoa natural que a constitui, conforme descrito em sua declaração anual de bens entregue ao órgão competente.

Justificou o veto explicando que a expressão "em qualquer situação" poderia gerar divergências com relação à aplicação do instituto da desconsideração da personalidade jurídica previsto no artigo 50 do CCB. A presidente entendeu por bem manter apenas as regras relativas à separação patrimonial previstas para as sociedades limitadas.

Apesar da lógica impecável, vez que de fato nosso ordenamento prevê diversas situações de responsabilização pessoal tanto de sócios quanto de administradores, não haveria necessidade do veto, pois a teoria da desconsideração da personalidade jurídica já está consolidada na prática jurídica brasileira. Mesmo diante do termo "em qualquer situação", isso não seria bastante para pôr em cheque a construção legislativa, doutrinária e jurisprudencial já consagrada no sentido de aceitar e aplicar - às vezes até mesmo em demasia - a disregard doctrine.

No entanto, tampouco se vê maiores prejuízos no veto presidencial, uma vez que o artigo 1.052 do CCB prevê expressamente a limitação da responsabilidade dos sócios da sociedade limitada, o qual será aplicado à EIRELI por força do artigo 980-A, $\S 6^{\circ}$ do CCB.

\subsection{Críticas à Lei $12.441 / 2011$}

\subsubsection{A natureza jurídica da EIRELI}

Com a promulgação da Lei 12.441/2011, diversas foram as críticas ao molde concebido para o novo instituto. Questiona-se, dentre outros 
aspectos, a sua natureza jurídica, se se trata de sociedade empresária ou de nova pessoa jurídica, de natureza autônoma.

A Lei 12.441/2011 utiliza, diversas vezes, expressões tipicamente empregadas para se referir a sociedades, tais como "capital social", "quotas" e "sócio". Além disso, como será visto adiante, o legislador tratou a "empresa" como sujeito de direito, ao invés de tratá-la como objeto de direito, divergindo do entendimento da doutrina sobre esse termo jurídico. Esses fatores, aliados à previsão de aplicação supletiva das regras das sociedades limitadas à EIRELI, poderia levar à crença de que a EIRELI possui uma natureza de sociedade.

No entanto, em função da modificação sofrida pelo artigo 44 do CCB, a EIRELI passou a integrar o rol das pessoas jurídicas admitidas no direito brasileiro, juntamente com as associações, as sociedades, as fundações, as organizações religiosas e os partidos políticos. Além disso, a Lei 12.441/2011 adicionou o Título I-A ao Livro II do CCB, separando as regras atinentes ao empresário individual e às sociedades empresárias das regras que dizem respeito à EIRELI.

Diante disso, e principalmente em razão da modificação do artigo 44, a EIRELI se caracteriza, efetivamente, como nova modalidade de pessoa jurídica, não se tratando de uma sociedade. Apesar de a sociedade unipessoal ser a melhor opção para se atingir o objetivo da Lei 12.441/2011, a alteração do artigo 44 é clara. O entendimento contrário seria contra legem.

A esse respeito, o Enunciado 469 da V Jornada de Direito Civil, promovida em 2011 pelo Conselho da Justiça Federal, também entendeu que "a empresa individual de responsabilidade limitada (EIRELI) não é sociedade, mas novo ente jurídico personificado"111.

As críticas à natureza jurídica da EIRELI se estendem, ainda, à escolha da sua nomenclatura, pois o legislador fez uso da expressão

\footnotetext{
${ }^{111}$ V Jornada de Direito Civil. Centro de Estudos Jurídicos do Conselho da Justiça Federal. Brasília, 2011. Disponível em http://www.jf.jus.br/cjf/cej-publ/Compilacao\%20enunciados\%20 aprovados1.pdf. Acesso em 08 de abril de 2012.
} 
"empresa" para se referir ao sujeito de direito. Wilges Ariana Bruscato afirma que é muito comum, "mesmo nos meios jurídicos mais autorizados, [a confusão] sobre os termos empresa, sociedade, empresário, firma, estabelecimento" $" 112$.

A esse respeito, ao se referir à teoria poliédrica de Asquini, Fabio Ulhoa Coelho ${ }^{113}$ leciona que

\begin{abstract}
Ele divisa, por conseguinte, quatro perfis na empresa: subjetivo, funcional, patrimonial (ou objetivo) e corporativo. Pelo primeiro, a empresa é vista como empresário, isto é, o exercente de atividade autônoma, de caráter organizativo e com assunção de risco. Pelo perfil funcional, identifica-se a empresa à própria atividade. Pelo terceiro perfil, corresponde ao patrimônio aziendal ou estabelecimento. E, por fim, pelo perfil corporativo, ela é considerada uma instituição, na medida em que reúne pessoas - empresário e seus empregados com propósitos comuns.
\end{abstract}

Nesse sentido, a empresa propriamente dita seria a atividade - perfil funcional. Atividade esta economicamente organizada para a produção e circulação de bens e serviços. A empresa é, portanto, objeto de direito e não sujeito. Diferentemente, a sociedade e o empresário são as pessoas que exploram a empresa. São eles, portanto, os sujeitos de direito, tanto ativo quanto passivo - perfil subjetivo.

O estabelecimento, por sua vez, é o conjunto de bens, corpóreos ou incorpóreos, materiais ou imateriais, destinados ao exercício da empresa perfil patrimonial. Sua natureza jurídica é de universalidade de fato. Tal como a empresa, o estabelecimento é objeto de direito, não sujeito. Já a firma é uma espécie de nome empresarial, tal qual a denominação social, empregada pelos empresários individuais.

Nota-se, diante disso, que a opção pelo nome "empresa individual" foi, no mínimo, infeliz. Como visto, o termo empresa designa a atividade exercida pelo empresário individual ou pela sociedade empresária. A empresa não é, ou pelo menos não era um sujeito de direito. A doutrina

\footnotetext{
${ }^{112}$ BRUSCATO, Wilges Ariana. Era uma vez a empresa individual de responsabilidade limitada. Disponível em http://www.wilges.com.br/eraumavez.pdf. Acesso em 08 de abril de 2012.

${ }^{113}$ COELHO, Fábio Ulhoa. Curso de Direito Comercial. $13^{\mathrm{a}}$ ed. São Paulo: Saraiva, 2009. v. 1. p. 18 .
} 
considera como sujeitos de direito o empresário e a sociedade, não a empresa.

O legislador nacional, contudo, optando pelo perfil subjetivo da teoria poliédrica de Asquini, transformou a empresa em sujeito de direito, criando uma nova pessoa jurídica e concedendo-lhe personalidade jurídica, com todos os efeitos daí advindos.

Tampouco possui, a empresa em si, responsabilidade limitada. Limitada é a responsabilidade do seu instituidor, visto que a EIRELI responderá perante seus credores com a integralidade de seu patrimônio. Essa crítica, todavia, não é de hoje. Logo na promulgação do novo CCB, muito se criticou quanto à nomenclatura dada às atuais sociedades limitadas, pois limitada é tão somente a responsabilidade dos seus sócios, que, nos termos do artigo 1.052 do $\mathrm{CCB}$, respondem apenas até o limite do capital social subscrito e não integralizado ${ }^{114}$.

Teria andado melhor o legislador se optasse pela denominação mais adequada ao novo instituto: empresário individual de responsabilidade limitada.

\subsubsection{Constituição da EIRELI por pessoa jurídica}

Outro aspecto da Lei 12.441/2011 objeto de intenso questionamento é a possibilidade, ou não, de constituição da EIRELI por pessoa jurídica. A confusão se origina da redação dada ao artigo 980-A do CCB, que determina que a EIRELI "será constituída por uma única pessoa titular da totalidade do seu capital social", e ao seu parágrafo único, que limita à pessoa natural que constituir a EIRELI a instituição de apenas 01 (uma) empresa dessa modalidade.

O caput do artigo 980-A não faz restrição quanto à instituição de EIRELI por pessoa jurídica, nem especifica qual tipo de pessoa poderá

\footnotetext{
${ }^{114}$ BRUSCATO, Wilges Ariana. Empresário Individual de Responsabilidade Limitada. São Paulo: Quartier Latin, 2005. p. 225 - 226.
} 
figurar como instituidor. Entende-se, assim, que a lei não pretendeu trazer essa vedação. A limitação prevista no artigo 980-A, $§ 2^{\circ}$ constitui uma especificidade aplicável apenas às pessoas naturais. Não há qualquer impossibilidade legal para que pessoas jurídicas constituam EIRELI.

Há, entretanto, quem discorde desse posicionamento. Os juristas que defendem restringir a EIRELI às pessoas naturais argumentam que a Lei 12.441/2011 não tinha o intuito de conceder essa faculdade às pessoas jurídicas. Não seria essa a mens legis, o espírito da norma. A partir de uma interpretação teleológica da lei, entendem tais juristas que o alvo da lei era os pequenos empreendedores, os integrantes do comércio informal, as iniciativas de menor porte, o que seria incompatível com a possibilidade de constituição da EIRELI por pessoa jurídica.

Em que pese a razoabilidade de tal argumento, ele não parece se sustentar quando se nota o capital mínimo exigido para a instituição de uma EIRELI - 100 (cem) salários mínimos, o que, hoje, se aproxima de R \$ 60.000,00 (sessenta mil reais). Ressalte-se, ainda, que o artigo 980-A exige que o capital esteja inteiramente integralizado à época da constituição da empresa.

Ora, como poderia prosperar a alegação de que pessoas jurídicas não podem instituir EIRELI's porque estas se direcionam às iniciativas de menor vulto quando se exige um capital mínimo, integralizado, de tal monta?

Não se defende no presente estudo que o público alvo da EIRELI não seja, de fato, o pequeno empreendedor e os comerciantes informais. $\mathrm{O}$ que não se admite é a justificação dessa suposta vedação às pessoas jurídicas porque não seria do espírito da lei, pelo menos não quando não há qualquer restrição expressa e nem mesmo implícita no texto legal.

Também se argumenta que a especificação das pessoas naturais constava dos projetos de lei que deram origem à Lei 12.441/2011. Ainda, defende-se que a exposição de motivos dos Projetos de Lei 4.605/2009 e 4.953/2009 apenas tratava do incentivo ao empresário individual - pessoa 
física. Por isso não poderia haver instituição de EIRELI por pessoa jurídica.

Entretanto, se a especificação constava dos textos originais dos projetos de lei e foi retirada no substitutivo apresentado pela Comissão de Constituição e Justiça e de Cidadania e aprovado pelo Congresso Nacional, é porque referida restrição não deveria existir.

A interpretação contrária se mostra pouco razoável. Por que haveria de subsistir uma vedação para pessoas jurídicas se o próprio legislador retirou-a do texto da norma? Não é adequada a interpretação legal pela qual se pressupõe o erro do legislador nem aquela que impõe restrições não previstas no texto legal.

$\mathrm{O}$ artigo $5^{\circ}$, II da CRFB, ao instituir que ninguém será obrigado a deixar de fazer algo senão em virtude de lei, deve ser interpretado no sentido de que o poder público não pode impor qualquer abstenção sem lei que o permita ${ }^{115}$. Leciona o ilustre José Afonso da Silva ${ }^{116}$ que "O princípio da legalidade é nota essencial do Estado de Direito. É, também, por conseguinte, um princípio basilar do Estado Democrático de Direito (...)".

Essa é a tese sob análise. Se a Lei 12.441/2011 não traz qualquer tipo de proibição à constituição de EIRELI por pessoa jurídica, não cabe nem ao intérprete nem ao administrador público proibi-la.

Assim, está equivocado o DNRC em sua determinação na Instrução Normativa 117/DNRC. Esse diploma institui o Manual de Atos de Registro de Empresa Individual de Responsabilidade Limitada - EIRELI, que deve ser observado pelas juntas comerciais na prática de atos de registro nele regulamentados ${ }^{117}$. No seu artigo 1.2.11, ele traz os impedimentos para ser titular de EIRELI e prevê que "Não pode ser titular de EIRELI a pessoa jurídica, bem assim a pessoa natural impedida por norma constitucional ou por lei especial”.

\footnotetext{
115 SILVA, José Afonso da. Curso de Direito Constitucional Positivo. $30^{\mathrm{a}}$ ed. São Paulo: Malheiros, 2008. p. 420.

116 SILVA, José Afonso da. Curso de Direito Constitucional Positivo. 30 a ed. São Paulo: Malheiros, 2008. p. 420.

${ }^{117}$ Instrução Normativa no 117 , de 22 de novembro de 2011. Disponível em http://www.dnrc.gov. br/Legislacao/IN\%20117\%202011.pdf. Acesso em 08 de abril de 2012.
} 
No mesmo sentido, o Enunciado 468 da V Jornada de Direito Civil, pelo qual "A empresa individual de responsabilidade limitada só poderá ser constituída por pessoa natural"118.

Reforçando a tese a favor da possibilidade de instituição da EIRELI por pessoa jurídica, o artigo $980-\mathrm{A}, \S 6^{\circ}$ prevê a aplicação subsidiária à EIRELI, no que couber, das regras instituídas para as sociedades limitadas e não há, nessas regras, nenhum impedimento para que pessoas jurídicas figurem como sócias em sociedades limitadas.

Cabe ressaltar, ainda, que a admissão da constituição de EIRELI por pessoa jurídica poderia contribuir para a organização administrativa dos grupos econômicos. Trata-se da "possibilidade de criação de um profit center juridicamente autônomo sobre cuja administração o 'sócio' tenha controle absoluto, podendo determinar livremente o fluxo de recursos no interior do grupo de sociedades" ${ }^{\text {119. }}$.

Recente decisão judicial veio agitar ainda mais o debate. A juíza Gisele Guida de Faria, da $9^{a}$ Vara da Fazenda Pública do Estado do Rio de Janeiro, proferiu decisão favorável ao pedido de liminar formalizado pela Purpose Brazil Llc e pela Purpose Campaings Brasil Ltda. no Processo ${ }^{\circ}$ 0054566-71.2012.8.19.0001.

As empresas impetraram mandado de segurança preventivo visando a que o Presidente da JUCERJA se abstivesse de rejeitar o arquivamento do ato de transformação da Purpose Campaings Brasil Ltda. em EIRELI por meio da concentração de todas as quotas do seu capital na Purpose Brazil Llc. Alternativamente, requeriam que se mantivesse a singularidade societária da Purpose Campaings Brasil Ltda. até a decisão final do processo.

Entendeu, a juíza, que

\footnotetext{
${ }^{118}$ V Jornada de Direito Civil. Centro de Estudos Jurídicos do Conselho da Justiça Federal. Brasília, 2011. Disponível em http://www.jf.jus.br/cjf/cej-publ/Compilacao\%20enunciados\%20 aprovados1.pdf. Acesso em 08 de abril de 2012.

${ }^{119}$ FILHO, Calixto Salomão. A sociedade unipessoal. São Paulo: Malheiros, 1995. p. 14.
} 
(...) o fumus boni iuris, por sua vez, também encontra-se evidenciado nos autos. Isto porque, da simples leitura das normas sob comento, verifica-se que há clara violação ao princípio segundo o qual 'onde a lei não distingue, não cabe ao intérprete distinguir'. (...) Decorrendo, pois, do princípio constitucional da legalidade máxima de que 'ninguém é obrigado a fazer, ou deixar de fazer algo, senão em virtude de lei', não cabia ao DNRC normatizar a matéria inserindo proibição não prevista na lei, que lhe é hierarquicamente superior, a qual se propôs a regulamentar. (...) Tendo havido a supressão do termo 'natural' do texto final da lei, pode-se concluir que o legislador pretendeu com tal ato, permitir/não proibir a constituição de EIRELI por qualquer pessoa, seja ela da espécie natural, seja ela da espécie jurídica. (...) ${ }^{120}$

Por fim, mostra-se incabível o argumento de Wilges Ariana Bruscato no sentido de não permitir à pessoa jurídica constituir EIRELI porque já existe um instituto que possibilita a unipessoalidade para as sociedades: a subsidiária integral ${ }^{121}$. Ocorre que, como já analisado, apesar de a subsidiária integral possuir um regime mais simples do que aquele previsto, em regra, para as sociedades anônimas, ainda se trata de instituto um tanto complexo e dispendioso para os acionistas. A subsidiária integral não se caracteriza, pois, como alternativa para a EIRELI.

\subsubsection{O capital mínimo e sua vinculação ao salário mínimo nacional}

O caput do artigo 980-A do CCB prevê que o capital da EIRELI, quando da sua instituição, deverá estar inteiramente integralizado e que ele não poderá ser inferior a 100 (cem) vezes o maior salário mínimo vigente no Brasil. Como se percebe da simples leitura do dispositivo, são muitos os questionamentos sobre a sua conformidade com o ordenamento jurídico nacional.

A análise das questões envolvendo o capital da EIRELI será dividida em (i) a exigência de capital mínimo, integralizado para a instituição da EIRELI; e (ii) a vinculação do capital mínimo ao salário mínimo nacional.

Antes de analisar esses pontos, merece destaque o trecho do parecer

\footnotetext{
${ }^{120} 9^{a}$ Vara da Fazenda Pública do Estado do Rio de Janeiro, MS n ${ }^{\circ}$ 0054566-71.2012.8.19.0001, Rio de Janeiro, 07 de março de 2012.

${ }^{121}$ BRUSCATO, Wilges Ariana. Apontamentos à empresa individual de responsabilidade limitada-EIRELI: A saga continua. Revista ÍndexJur. Suplemento Especial - EIRELI, dezembro de 2011.
} 
da Comissão de Constituição e Justiça e de Cidadania, de relatoria do Deputado Marcelo Itagiba, na qual fica clara a real intenção da instituição de capital mínimo:

\begin{abstract}
Registro, também, que, considerando que se faz conveniente delimitar, em proporção razoável, o porte da organização que se pode constituir como empresa individual, a fim de que não se desvirtue a iniciativa nem esta se preste a meio e ocasião para dissimular ou ocultar vínculo ou relação diversa, propugnamos introduzir parâmetro mínimo apto a caracterizar a pessoa jurídica de que ora se trata, fazendo supor que se reúnem suficientes elementos de empresa, como sede instalada ou escritório, equipamentos etc., tal como se fez para caracterizar microempresas e o empresário individual, nas respectivas leis reguladoras. Com este propósito, estabelecemos que o capital social não deva ser inferior ao equivalente a 100 salários mínimos, montante a partir do qual se tem por aceitável a configuração patrimonial da empresa individual. A tanto, emendamos a redação dada ao caput do art. 985-A proposto (art. 980-A), a ser aditado ao Código Civil por força do art. $2^{\circ}$ do Projeto. (grifado) ${ }^{122}$
\end{abstract}

O direito societário brasileiro não prevê, genericamente, nenhuma outra hipótese de exigência de capital mínimo para constituição de sociedades $^{123}$, nem de patrimônio mínimo para registro como empresário individual. Tampouco há casos em que se requer, como regra geral, a integralização total do capital social para a constituição da sociedade. Nesse aspecto, a Lei 12.441/2011 se mostra mais rígida com a EIRELI do que o CCB e a LSA com as sociedades limitadas e as sociedades anônimas. Ela instituiu exigência que não existia para outros tipos societários, dispensando à EIRELI um tratamento desigual e desfavorável.

Segundo Wilges Ariana Bruscato ${ }^{124}$, esse tratamento desigual e desfavorável viola o princípio da isonomia e está em desacordo com o artigo $5^{\circ}$, caput da CRFB. Além de inconstitucional, a autora argumenta que tal exigência é inoportuna, vez que possui aptidão para retirar do novo

\footnotetext{
${ }^{122}$ Parecer da Comissão de Constituição e Justiça e de Cidadania, Câmara dos Deputados. Disponível em http://www.camara.gov.br/proposicoesWeb/fichadetramitacao?idProposicao= 422915. Acesso em 08 de abril de 2012.

${ }^{123}$ A Lei 6.019/1974 exige que a empresa de trabalho temporário possua um capital social mínimo de 500 (quinhentas) vezes o maior salário mínimo vigente no Brasil. Do mesmo modo, a Lei 7.102/1983 requer que a empresa especializada que explore atividade de segurança e vigilância tenha um capital integralizado equivalente a 1.000 (mil) Ufir.

${ }^{124}$ BRUSCATO, Wilges Ariana. Apontamentos à empresa individual de responsabilidade limitada-EIRELI: A saga continua. Revista ÍndexJur. Suplemento Especial - EIRELI, dezembro de 2011.
} 
instituto a sua eficácia, e que o valor exigido - R\$ 62.200,00 (sessenta e dois mil e duzentos reais), atualmente - violaria o princípio da livre iniciativa preceituado no artigo 170, caput da CRFB.

A exigência de capital mínimo em valor tão alto e totalmente integralizado no ato de constituição da EIRELI poderá, realmente, impedir parte dos empresários individuais e comerciantes informais de aproveitarem os seus benefícios. Apenas da análise do artigo 68 da Lei Complementar 123/2006, que prevê o microempreendedor, já se identifica uma parcela dos empresários que estarão excluídos da EIRELI - tal dispositivo prevê renda bruta anual de até $\mathrm{R} \$ 36.000,00$ (trinta e seis mil reais) para a qualificação como microempreendedor.

Com isso, um dos objetivos primordiais da Lei 12.441/2011 restará frustrado, qual seja, o fim das sociedades fictícias, simuladas ou aparentes. De fato, não se concebe como um instituto que exige um aporte inicial tamanho poderá se sobrepor às sociedades fictícias, para as quais não se exige um capital inicial mínimo nem a obrigação de integralizá-lo desde a constituição. Para os pequenos e micro empresários, a opção societária apresenta um custo financeiro menor.

Para aqueles que concordam com a exigência de capital mínimo para a EIRELI, no entanto, não há violação aos princípios constitucionais. De acordo com Marlon Tomazette, "o princípio da livre iniciativa não representa uma liberdade econômica absoluta" ${ }^{125}$. O autor defende que o Estado pode limitar a liberdade empresarial em respeito aos demais princípios constitucionais. É necessário, para tanto, fazer uma ponderação de princípios. Nesse sentido, a parte final do artigo 980-A não inviabilizaria a constituição de EIRELI e concederia, ainda, algum tipo de proteção aos credores da empresa.

Marlon Tomazette dá notícia de outros países com exigências

TOMAZETTE, Marlon. ADI sobre o capital mínimo da EIRELI. Disponível em http://direitocomercial.com/?p=258. Acesso em 08 de abril de 2012. 
similares, como a Itália, a Argentina, a China e a Índia ${ }^{126}$. No entanto, o Doing Business 2012 do Banco Mundial ${ }^{127}$, relatório utilizado por Malon Tomazette para obter tal informação ${ }^{128}$, informa que "o capital mínimo exigido [para a constituição de sociedades] pode constituir um obstáculo a potenciais empreendedores". A abolição da exigência de capital mínimo é anunciada pelo Banco Mundial como uma boa prática dos países para facilitar a abertura de sociedades e constitui 01 (um) dos dados utilizados pelo banco para classificar a facilidade para fazer negócios em determinado país.

O parecer da Comissão de Constituição e Justiça e de Cidadania justificou que o capital mínimo seria necessário para que a EIRELI tivesse um porte que evitasse seu uso para fraude ou dissimulação. Ora, como se viu, o instituto a ser aplicado nesse caso é a desconsideração da personalidade jurídica. $\mathrm{O}$ direito brasileiro já oferece ferramentas para tal e o capital mínimo não deveria ser utilizado para isso. A exigência legal apenas fará com que muitos empresários que poderiam se beneficiar do novo instituto sejam excluídos dele.

Contudo, apesar de a exigência ser inoportuna, os princípios constitucionais elencados acima, de fato, não são absolutos e no ordenamento jurídico brasileiro há diversos exemplos em que alguns princípios são aplicados em detrimento de outros. Não há, portanto, inconstitucionalidade no capital mínimo exigido pela Lei 12.441/2011.

Merece questionamento, ainda, a constitucionalidade da vinculação do capital mínimo ao salário mínimo. O artigo $7^{\circ}$, IV da CRFB prevê, expressamente, que é direito do trabalhador o "salário mínimo, (...) com reajustes periódicos que lhe preservem o poder aquisitivo, sendo vedada sua vinculação para qualquer fim”.

\footnotetext{
126 TOMAZETTE, Marlon. ADI sobre o capital mínimo da EIRELI. Disponível em http://direitocomercial.com/?p=258. Acesso em 08 de abril de 2012.

127 Doing Business 2012. Banco Internacional de Reconstrução e Desenvolvimento/Banco Mundial. Disponível em http://portugues.doingbusiness.org/ /media/FPDKM/Doing\%20Business /Documents/Annual-Reports/Foreign/DB12-Portuguese.pdf. Acesso em 11 de abril de 2012.

${ }^{128}$ Observe-se, no entanto, que a fonte utilizada por Marlon Tomazette foi o Doing Business 2011, do Banco Mundial, e não o Doing Business 2012, ora referido.
} 
O dispositivo acima não apresenta ressalvas nem abre exceções em que a vinculação estaria autorizada. Ainda assim, a jurisprudência do STF é pacífica no sentido de que a proibição do artigo $7^{\circ}$, IV se restringe à indexação de prestações periódicas ${ }^{129}$, o que significa que ela não seria aplicável em casos como, por exemplo, o valor do capital mínimo. Dessa forma, a vinculação ora referida não é inconstitucional.

Para elucidar a questão, o PPS propôs a ADI n ${ }^{\circ} 4.637^{130}$, requerendo a declaração de inconstitucionalidade com redução de texto da parte final do caput do artigo 980-A do CCB. Na sua petição inicial, o PPS aduz as mesmas razões levantas por Wilges Ariana Bruscato. Defende que a vinculação do capital ao salário mínimo é vedada pelo texto constitucional e que a própria exigência de capital mínimo viola o princípio da livre iniciativa. A decisão do STF será, certamente, muito aguardada por juristas e empresários.

Enquanto não se tem uma decisão final a esse respeito, a Justiça Federal do Estado de São Paulo proferiu, recentemente, uma decisão em

129 “ARGUIÇÃO DE DESCUMPRIMENTO DE PRECEITO FUNDAMENTAL. MEDIDA CAUTELAR. ARTIGO $3^{\circ}$ DA LEI FEDERAL N. 6.194. SEGURO OBRIGATÓRIO. PRECEITO QUE DISCIPLINA OS VALORES PAGOS EM RAZÃO DE DANOS PESSOAIS CAUSADOS POR VEÍCULOS AUTOMOTORES DE VIA TERRESTRE, OU POR SUA CARGA, A PESSOAS TRANSPORTADAS OU NÃO. FIXAÇÃO DOS VALORES EM SALÁRIOS MÍNIMOS. VIOLAÇÃO DO DISPOSTO NO ARTIGO $7^{\circ}$, INCISO IV, DA CONSTITUIÇÃO DO BRASIL. FUMUS BONI IURIS E PERICULUM IN MORA NÃO CARACTERIZADOS. MEDIDA CAUTELAR INDEFERIDA. 1. O artigo $3^{\circ}$ da Lei federal n. 6.194 vincula ao salário mínimo as indenizações pagas em decorrência de morte, invalidez permanentes e despesas de assistência médica e suplementares resultantes de acidentes causados por veículos automotores de via terrestre. 2. O Tribunal dividiu-se quanto à caracterização do fumus boni iuris e do periculum in mora: i) votos majoritários que entenderam ausentes o fumus boni iuris e o periculum in mora, eis que o artigo $7^{\circ}$, inciso IV, da Constituição do Brasil não vedaria a utilização do salário mínimo como parâmetro quantificador de indenização e a Lei n. 6.194 teria sido inserida no ordenamento jurídico em 1.974, respectivamente; ii) votos vencidos, incluindo o do Relator, no sentido de que o fumus boni iuris estaria configurado na impossibilidade de vinculação do salário mínimo para fins remuneratórios, indenizatórios --- embora em situações excepcionais esta Corte tenha manifestado entendimento diverso --- e o periculum in mora evidenciado pela existência de inúmeras decisões judiciais que, aplicando o texto normativo impugnado, impondo às entidades seguradoras obrigações pecuniárias. 3. Medida cautelar indeferida, contra o voto do Relator, que determinava a suspensão do trâmite dos processos em curso que respeitem à aplicação do artigo $3^{\circ}$ da Lei $\mathrm{n}$. 6.194, de 19 de dezembro de 1.974, até o julgamento final do feito." STF, ADPF n ${ }^{\circ}$ 95/DF, Rel. Ministro Eros Grau, 31 de agosto de 2006. No mesmo sentido, a Súmula Vinculante $\mathrm{n}^{\circ}$ 4, que prevê que "Salvo nos casos previstos na Constituição, o salário mínimo não pode ser usado como indexador de base de cálculo de vantagem de servidor público ou de empregado, nem ser substituído por decisão judicial.” STF, Súmula Vinculante $\mathrm{n}^{\circ}$ 4. Disponível em http://www.stf.jus.br/portal/jurisprudencia/listarJurisprudencia.asp?s1=\%28\%284.NUME.\%29\%2 9+E+S.FLSV.\&base=baseSumulasVinculantes. Acesso em 11 de abril de 2012.

${ }^{130}$ STF, ADI n ${ }^{\circ} 4.637$, Rel. Ministro Gilmar Mendes, Brasília, 12 de agosto de 2011. 
sentido contrário em um mandado de segurança impetrado pela empresa Villagarcia Consultoria Empresarial Eireli, contra o Presidente da JUCESP. A empresa buscava medida liminar determinando à autoridade impetrada que arquivasse o seu ato constitutivo, o qual havia sido condicionado à existência de capital não inferior a 100 (cem) salários mínimos. Todavia, o magistrado entendeu ser improcedente a pretensão da parte autora, justificando como segue:

(...) existem precedentes plenamente integrados ao ordenamento jurídico brasileiro há décadas sobre a imposição de capital mínimo, situação que demonstra plenamente a sua razoabilidade e bom senso. São os casos de empresas que pretendem atuar na atividade econômica de 'mão de obre temporária' (Lei no 6.019/74) e na atividade econômica de 'segurança ou vigilância' (Lei n ${ }^{\circ}$ 7.102/83, alterada pelas Leis $n^{\circ}$ 9.017/95 e $n^{\circ} 11.718 / 08$ ). (...) Por outro lado, a impetrante não se encontra impedida de iniciar suas atividades, uma vez que a constituição na forma de empresa individual de responsabilidade limitada não é a única possibilidade colocada à sua disposição. De seu turno, importa salientar que a vinculação do capital social da empresa ao salário mínimo não afronta o ordenamento jurídico em vigor, porquanto a vedação constitucional busca tão somente impedir a sua utilização como indexador de prestações periódicas. ${ }^{131}$

Por fim, merece lembrança o legislador francês que, em tempos de crise, retirou da EURL a exigência de capital mínimo. A EIRELI se aproximaria mais do propósito inicial dos projetos de lei que lhe deram origem se a Lei 12.441/2011 não trouxesse essas exigências infelizes.

${ }^{131} 19^{a}$ Vara Cível da Justiça Federal do Estado de São Paulo, MS n 0002421-54.2012.4.03.6100, São Paulo, 22 de março de 2012. 


\section{CONCLUSÃO}

Apenas em 2011 o Brasil passou a admitir a proteção patrimonial do empresário individual. Antes disso, o comerciante que pretendesse empreender individualmente não tinha outra opção. Caso não seguisse o caminho das sociedades fictícias, sujeitaria o seu patrimônio pessoal às dívidas de sua empresa. Mesmo diante da difusão das sociedades fictícias e dos riscos que isso representa para os sócios de tais sociedades, o legislador aguardou até 2011 para oferecer uma solução para essa situação.

Esse cenário foi modificado pela Lei $12.441 / 2011$ e pela criação da EIRELI. Apesar da iniciativa louvável do legislador, a EIRELI se caracteriza por ser um modelo teoricamente complexo, cuja regulamentação já nasceu esparsa e envolta em incertezas. O melhor modelo a ser adotado teria sido o da sociedade unipessoal em função das diversas vantagens que ele apresenta em relação às outras opções.

Os modelos não societários de proteção ao empresário individual criam empecilhos para a circulação da empresa e deixam a desejar em versatilidade. Ora impossibilitando a transferência como um todo da atividade, ora implicando a necessidade de reestruturação e criação de uma sociedade, nem o patrimônio de afetação nem a personalização de um novo ente logram oferecer vantagens que não possam ser alcançadas pela sociedade unipessoal.

Esta, inclusive, apresenta 01 (um) único óbice para ser admitida em lei: a barreia teórica. Como se verificou, as sociedades unipessoais não apresentam maiores riscos do que os da sociedade pluripessoal. O instituto da desconsideração da personalidade jurídica é eficiente para a proteção de terceiros e pode ser igualmente aplicado às 02 (duas) espécies societárias. Apenas com a superação das teorias contratualistas e com a aceitação da concepção da sociedade como instituição ou como um contrato-organização é possível transpor essa barreira.

Essa barreira teórica vinha sendo superada, aos poucos, pelo direito 
brasileiro. As subsidiárias integrais e a unipessoalidade temporária superveniente demonstram que a unipessoalidade não só é possível, mas também apropriada em diversos casos. Essas hipóteses específicas permitem uma melhor organização dos grupos econômicos e a economia de recursos quando, por uma eventualidade, o quadro social se vê reduzido a 01 (um) sócio.

O mesmo entendimento se difundiu em diversos países europeus, principalmente depois da edição da $12^{\mathrm{a}}$ Diretiva. Tanto Portugal quanto a França, cujos institutos de proteção do comerciante singular datam de antes da $12^{\mathrm{a}}$ Diretiva, optaram por combinar o modelo societário e o não societário em suas legislações. Curiosamente, esses países tiveram experiências que os levaram a introduzir os seus modelos em ordem diferente.

Portugal, por um lado, iniciou pelo EsIRL, mas logo percebeu que a complexidade desse instituto não permitiu que ele servisse ao seu propósito. Diante disso, criou a SQU 10 (dez) anos depois, trazendo mais 01 (uma) opção para o empresário individual. A França, por outro lado, fez o caminho contrário. Verificou-se que naquele país a EURL não teve adesão do meio empresarial e, recentemente, o legislador francês criou o EnIRL.

Em face dessa experiência se percebe que apenas com o decorrer dos anos será possível analisar se o modelo escolhido pelo legislador brasileiro atenderá, efetivamente, às necessidades nacionais. É preciso admitir que a quantidade de EIRELI's constituídas na JUCESP nos pouquíssimos meses de vigência da lei indica que a resposta a esse questionamento será afirmativo. A adoção do modelo societário, mais simples, prático e viável, talvez tivesse atraído ainda mais empresários, mas isso jamais se saberá ao certo.

O que se sabe, efetivamente, é que as breves palavras do legislador nacional deixaram muitas dúvidas sobre o regramento da EIRELI, principalmente quanto à sua natureza jurídica; à sua forma de constituição; à eventual vedação à constituição por pessoa jurídica; à possibilidade de 
regência supletiva pelas regras das sociedades anônimas, ou apenas por aquelas referentes às subsidiárias integrais; ao cabimento da divisão do capital em quotas; à possibilidade de constituição do capital com bens e/ou serviços; à constitucionalidade do capital mínimo e sua vinculação ao salário mínimo; à permissão para que terceiros possam exercer a administração da EIRELI, dentre outras ${ }^{132}$.

Dentre essas incertezas, optou-se por analisar a natureza jurídica da EIRELI, a possibilidade de ela ser constituída por pessoa jurídica e a inconstitucionalidade do capital mínimo vinculado ao salário mínimo por serem aspectos com maior impacto no novo instituto, pelo menos nesse momento inicial.

Restou claro que a EIRELI é uma nova pessoa jurídica, autônoma e desvinculada das sociedades empresárias. Embora a Lei 12.441/2011 faça diversas menções a expressões societárias típicas, o próprio diploma legal incluiu a EIRELI em inciso próprio no rol das pessoas jurídicas admitidas no direito brasileiro.

Mesmo na qualidade de pessoa jurídica autônoma, a EIRELI é regida supletivamente pelas regras das sociedades limitadas. Esse aspecto, conjugado com o fato de não haver na Lei 12.441/2011 nenhuma proibição para sua constituição por pessoas jurídicas, apenas reforça o fato de que não há qualquer vedação nesse sentido. Em razão da completa ausência de vedação legal, as pessoas jurídicas são livres para constituir EIRELI's, inclusive sem o limite de 01 (uma) EIRELI que existe para as pessoas naturais.

Seguindo igual raciocínio, por não haver uma restrição nesse sentido no direito brasileiro se conclui que não é inconstitucional o capital mínimo exigido pela Lei 12.441/2011 nem a sua vinculação ao salário mínimo. O STF já decidiu que o impedimento da CRFB relativo à vinculação ao salário mínimo se refere a prestações periódicas, o que não se aplica à

132 AQUINO, Leonardo Gomes de. Empresa individual de responsabilidade limitada: considerações sobre o novel instituto. Consulex. Revista Jurídica, Distrito Federal (Brasília), v. 15, n. 350, p.62-63, ago. 2011. 
hipótese analisada.

No entanto, ainda que não haja inconstitucionalidade, essa previsão da Lei 12.441/2011 é inconveniente e infeliz. Ela não contribuirá para a proteção de terceiros, resultando apenas em uma maior ineficácia do instituto. Ao invés de ser uma opção viável para a proteção dos empresários comuns, ela ficará restrita aos empreendimentos de maior vulto e não conseguirá abolir as sociedades fictícias.

A iniciativa do legislador, realmente, merece aplausos, pois a limitação da responsabilidade do comerciante individual já deveria ter sido admitida no Brasil há tempos. Agora caberá à doutrina e à jurisprudência dar ao novo instituto os contornos necessários para que a sua finalidade possa ser atingida em sua integralidade. Somente com a prática jurídica será possível observar se a EIRELI terá um fim similar ao EsIRL ou se o Brasil se aproximará da experiência francesa. 


\section{REFERÊNCIAS BIBLIOGRÁFICAS}

V Jornada de Direito Civil. Centro de Estudos Jurídicos do Conselho da Justiça Federal. Brasília, 2011. Disponível em http://www.jf.jus.br/. Acesso em 08 de abril de 2012.

ABRÃO, Nelson. Sociedade por quotas de responsabilidade limitada. $7^{\mathrm{a}}$ ed. São Paulo: Saraiva, 2000.

AQUINO, Leonardo Gomes de. Empresa individual de responsabilidade limitada: considerações sobre o novel instituto. Consulex. Revista Jurídica. Distrito Federal (Brasília), v. 15, n. 350, p.62-63, ago. de 2011.

BARBIERI, Fabrício de Vecchi; HENTZ, Luiz Antonio Soares. A sociedade unipessoal no direito português - considerações atuais. Revista Eletrônica do Conselho Federal da OAB, n. 8, p. 120-169, nov./dez. de 2009.

BORBA, José Edwaldo Tavares. Direito Societário. $11^{\mathrm{a}}$ ed. Rio de Janeiro: Renovar, 2008. 576 p.

BRUSCATO, Wilges Ariana. Empresário Individual de Responsabilidade Limitada. São Paulo: Quartier Latin, 2005.

BRUSCATO, Wilges Ariana. Era uma vez a empresa individual de responsabilidade limitada. Disponível em http://www.wilges.com.br/. Acesso em 08 de abril de 2012.

BRUSCATO, Wilges Ariana. Apontamentos à empresa individual de responsabilidade limitada-EIRELI: a saga continua. Revista ÍndexJur. Suplemento Especial - EIRELI, dez. de 2011. 
CARAPETCOV, Thiago. O EIRELI não é de hoje. Disponível em http://thiagocarapetcov.blogspot.com.br/. Acesso em 08 de abril de 2012.

CARMO, Eduardo de Sousa. Sociedade unipessoal por cotas de responsabilidade limitada. Revista de Direito Mercantil, Industrial, Econômico e Financeiro. São Paulo, v. 28, n. 75, p.41-48, jul. de 1989.

CARVALHOSA, Modesto. Comentários à Lei de Sociedades Anônimas. $4^{\circ}$ vol. tomo I. $4^{\text {a }}$ ed. São Paulo: Saraiva, 2009.

CARVALHOSA, Modesto. Comentários à Lei de Sociedades Anônimas. $4^{\circ}$ vol. tomo II. $3^{\text {a }}$ ed. São Paulo: Saraiva, 2009.

COELHO, Fábio Ulhoa. Curso de Direito Comercial. v. 1. 13 ${ }^{\mathrm{a}}$ ed. São Paulo: Saraiva, 2009.

COELHO, Fábio Ulhoa. Curso de Direito Comercial. v. 2. 13 ed. São Paulo: Saraiva, 2009.

CORDEIRO, António Menezes. Direito Europeu das Sociedades. Coimbra: Almedina, 2005.

CORREIA, António de Arruda Ferrer. Sociedades Fictícias e Unipessoais. Coimbra: Atlântida, 1948.

COSTA, Ricardo Alberto Santos. A sociedade por quotas unipessoal no direito português. Coimbra: Almedina, 2002.

DAIGRE, Jean-Jacques. La société unipersonnelle. Revue internationale de droit comparé. Paris, Société de Législation Comparée, v. 42, n. 2, 1990. 
EIZIRIK, Nelson. A Lei das S/A Comentada. vol. III. São Paulo: Quartier Latin, $2011.640 \mathrm{p}$.

FACCHIM, Tatiana. A sociedade unipessoal como forma organizativa da micro e pequena empresa. São Paulo. 2010. 126 p. Dissertação (Mestrado em Direito Comercial) - Faculdade de Direito da Universidade de São Paulo.

FIGUEIREDO, Paulo Roberto Costa. Subsidiaria integral: a sociedade unipessoal no direito brasileiro. São Paulo: Saraiva, 1984.

FILHO, Alfredo Lamy; PEDREIRA, José Luiz Bulhões. Direito das Companhias. vol. I. $1^{\text {a }}$ ed. Rio de Janeiro: Forense, 2009.

FILHO, Alfredo Lamy; PEDREIRA, José Luiz Bulhões. Direito das Companhias. vol. II. $1^{\text {a }}$ ed. Rio de Janeiro: Forense, 2009.

FILHO, Antônio Martins. Limitação da Responsabilidade do Comerciante Individual. Tese apresentada ao Congresso Jurídico comemorativo do cinquentenário de fundação da Faculdade de Direito da Universidade do Rio Grande do Sul. Publicação da Faculdade de Direito do Ceará, maio de 1950.

FILHO, Calixto Salomão. A sociedade unipessoal. São Paulo: Malheiros, 1995.

ISFER, Edson. Sociedades unipessoais e empresas individuais responsabilidade limitada. Curitiba: Juruá, 1996. p. 192. 
L'EIRL: Un nouveau statut juridique et fiscal pour l'entrepreneur. Apresentação disponível em http://www.eirl.fr/multimedia/diaporamas. Acesso em 10 de maio de 2012.

LOBO, Jorge Joaquim. Pessoas jurídicas podem constituir empresas individuais. ADV: Advocacia Dinâmica - Informativo. Rio de Janeiro, n. 6, p. 88-87, fev. de 2012.

PASCOAL, Tania Negri. Sociedades unipessoais. Revista Forense. Rio de Janeiro, v. 80, n. 287, p. 148-157, jul. de 1984.

PEREIRA, Caio Mário da Silva. Instituições de Direito Civil. vol. I. $22^{\mathrm{a}}$ ed. Rio de Janeiro: Forense, 2008.

PINHEIRO, Frederico Garcia. Empresa individual de responsabilidade limitada. Revista Magister de Direito Empresarial, Concorrencial e do Consumidor. Porto Alegre, v. 7, n. 41, p. 59-78, out./nov. 2011.

SALES, Fernando Augusto de Vita Borges de. Novos rumos do Direito Empresarial brasileiro: a lei n. 12.441/2011 e a empresa individual de responsabilidade limitada. ADV: Advocacia Dinâmica - Informativo. Rio de Janeiro, n. 37, p. 616-613, set. de 2011.

SILVA, José Afonso da. Curso de Direito Constitucional Positivo. $30^{\mathrm{a}}$ ed. São Paulo: Malheiros, 2008.

TOMAZETTE, Marlon. ADI sobre o capital mínimo da EIRELI. Disponível em http://direitocomercial.com/. Acesso em 08 de abril de 2012.

WORLD BANK. Doing Business 2012. Disponível em http://www.doingbusiness.org/. Acesso em 11 de abril de 2012. 
STF, ADI $n^{\circ}$ 4.637, Rel. Ministro Gilmar Mendes, Brasília, 12 de agosto de 2011.

STF, ADPF n 95/DF, Rel. Ministro Eros Grau, Brasília, 31 de agosto de 2006.

$9^{\text {a }}$ Vara da Fazenda Pública do Estado do Rio de Janeiro, MS n ${ }^{\circ 0054566-}$ 71.2012.8.19.0001, Rio de Janeiro, 07 de março de 2012.

$19^{a}$ Vara Cível da Justiça Federal do Estado de São Paulo, MS n $0002421-$ 54.2012.4.03.6100, São Paulo, 22 de março de 2012. 